CAHIER DE RECHERCHE \#1621E

WORKING PAPER \#1621E

Département de science économique

Department of Economics

Faculté des sciences sociales

Faculty of Social Sciences

Université d'Ottawa

University of Ottawa

\title{
The Persistence of Trade Policy in China After WTO Accession*
}

\author{
Jason Garred $^{\dagger}$
}

November 2016

\footnotetext{
*I thank Robin Burgess, Thomas Sampson and Daniel Sturm for their valuable input and support, along with Esther Ann Bøler, Francisco Costa, Réka Juhász, Sam Marden, Dennis Novy, Emanuel Ornelas, Gianmarco Ottaviano, Stephen Redding and Qinghua Tang, and discussants and seminar participants at the London School of Economics, Bank of Canada, McGill, Ottawa, Waterloo, Alberta School of Business, Oxford, the Northeast Universities Development Consortium (NEUDC) Conference, the China Economics Summer Institute, the Annual Conference of the Canadian Economics Association, the Centre for Economic Performance Annual Conference and the Globalisation and Economic Policy Postgraduate Conference.

${ }^{\dagger}$ Department of Economics, University of Ottawa, 120 University Private, Ottawa, Ontario, Canada, K1N 6N5; Email: Jason.Garred@uottawa.ca.
} 


\begin{abstract}
Import tariffs have fallen steeply worldwide over the last several decades, but has trade policy persisted through a rise in the use of other instruments? I study this question in the context of China's 2001 accession to the World Trade Organization, using panel data on Chinese export policies. I find that after its entry into WTO, the distribution of China's export restrictions across industries increasingly resembles the inverse of its pre-WTO import tariff schedule. The evidence suggests that increases in export restrictions are likely to have partly restored China's pre-WTO pattern of industrial protection.
\end{abstract}

JEL Classification: F13, F14, O13, O24. 


\section{Introduction}

A striking stylized fact about the international economy of the last several decades is the dramatic worldwide decline in the most widely observed instrument of trade policy: the import tariff. Much of this decline has been credited to the GATT/WTO process of multilateral trade negotiations, in which governments have committed to the implementation of ever smaller tariffs. But does the demise of the import tariff signal a retreat from activist trade policy among governments, or has trade policy simply persisted in other forms instead?

Long-established results in international trade theory suggest that other policy instruments may partially or entirely reproduce the effects of import tariffs. This may be accomplished even with policies that only indirectly affect imports; for instance, symmetries between the effects of export taxes and import tariffs in general equilibrium have been known to economists at least since the work of Lerner (1936). Yet while we have excellent data on import tariffs across products, countries and time, there is little systematic information on countries' usage of the other instruments that could substitute for tariffs in the implementation of their trade and industrial policies. This gap in the data leaves us unable to fully judge the extent to which such policies remain an active feature of the global economy, or establish the effectiveness of GATT/WTO negotiations in actually changing governments' behaviour.

This issue is of particular relevance to developing countries, for whom the instruments of trade policy, especially import tariffs, have historically been important tools of industrial strategy. While some observers have suggested that there is still much scope for less developed countries to implement industrial policies in the current multilateral system (e.g. Rodrik 2004), others have portrayed multilateral trade agreements as overly restrictive in this respect (e.g. Chang 2002). Here, I consider whether participation in WTO, and the accompanying restrictions on policy choice, have served as an effective constraint on the pattern of industrial protection of China - a developing country with a well-known history of interventionist economic policy, and the most important recent entrant into WTO.

China's 2001 entry into WTO allowed it to benefit from improved access to foreign markets, including permanent most-favoured-nation status in the United States. At the same time, in order to secure the assent of incumbent members to its WTO accession, China was also required to agree to changes in its own policies. For example, like other WTO members, China pledged as a condition of its accession to permanently keep its import tariffs below agreed maximum levels. This required cuts to its pre-WTO tariffs, and a resulting change in the pattern of protection across Chinese industries.

However, although these tariff cuts have been successfully completed, China has recently been the subject of trade disputes involving several other policies, such as domestic content requirements, preferential loans and discriminatory tax treatment. This raises the question of whether such policies may have partly restored China's pre-WTO pattern of industrial protection. As noted above, economic theory suggests that China could use various instruments to achieve trade or industrial policy goals previously accomplished with import tariffs. Here, I consider one particularly important class of instruments for which comprehensive and readily quantifiable data on Chinese policies is available: export restrictions. 


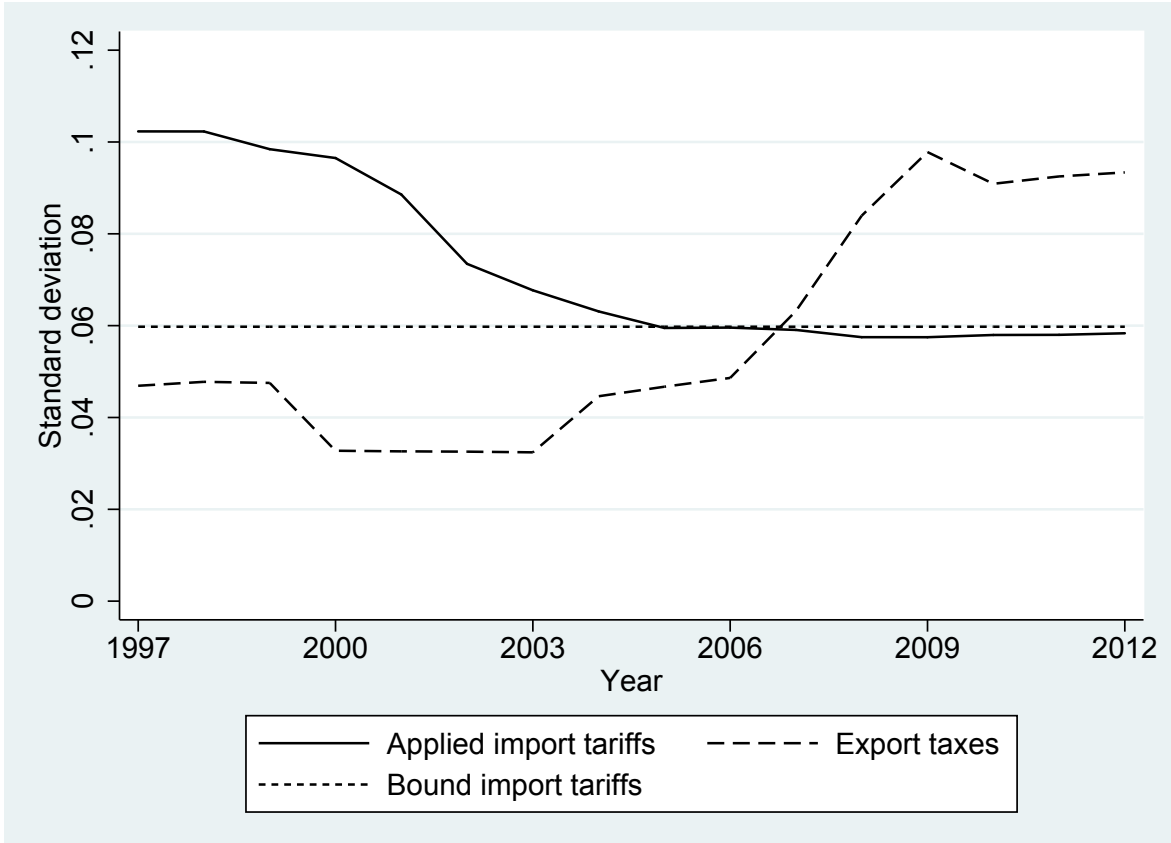

Figure 1: Standard deviation of China's applied and bound import tariffs and export tax equivalents of export VAT rebate policies and export duties across nonagricultural products, 1997 to 2012

In particular, I gather panel data on several instruments for which, like import tariffs, product-level policy schedules are published frequently in China. Figure 1 plots the standard deviation across products of import tariffs and the export tax equivalents of two of these instruments over time. As shown in the figure, I find that compression in China's tariff schedule due to its WTO accession commitments has been followed by a rise in variation in export restrictions across products. Moreover, I document in the empirical analysis below that these post-accession changes in China's export restrictions are systematically related to its pre-WTO schedule of import tariffs.

I begin by observing that industries protected by higher import tariffs before WTO accession were subsequently given relatively greater export support via smaller increases in export restrictions. Similarly, post-accession rises in export restrictions are also negatively related to China's pre-WTO non-tariff import barriers. This suggests that in the presence of intra-industry trade, China's export policies support a similar set of industries to those favoured by its pre-WTO pattern of import protection.

I then consider inter-industry relationships, showing that while the sectors with the largest pre-WTO tariffs were producers of goods relatively downstream in the value chain, China's subsequent export tax rises have been concentrated in raw materials industries. In theory, by imposing export taxes on raw materials, an exporter of these goods (such as China, which is a major producer of a wide range of raw materials) can generate a wedge between their domestic and world prices, supporting domestic downstream firms by providing them with an input cost advantage. Indeed, the US and EU have twice taken China to the 
WTO's dispute settlement mechanism over its export restrictions on raw materials, with the claim that these are used to support downstream industries. I find that downstream sectors indirectly protected through relatively lower input tariffs before WTO accession were subsequently supported via larger increases in export taxes on inputs from the same industries.

Finally, I examine whether the recent changes in China's export restrictions have been associated with changes in Chinese export patterns. As expected, I observe a negative relationship between export taxes and exports, along with a positive relationship between upstream export taxes and exports of downstream products. I also find that industries subject to larger export restrictions have a lower ratio of exports to total sales, suggesting that sales of local raw materials have been diverted to the domestic market.

These findings may be interpreted in two closely related ways. First, by requiring China to bind its import tariffs below certain levels, WTO accession restricted China's flexibility to use across-industry variation in import policy to protect some industries relative to others. However, trade policy has nonetheless persisted in China through increasing variation across industries in export restrictions, which have tended to support the same industries that benefited from tariff protection before China's WTO accession. Second, since the tariff reductions required as conditions of China's accession are highly correlated to its pre-WTO tariff levels, China's recent export policy changes have partly offset these tariff cuts. Either interpretation suggests that a full assessment of the changes in China's trade policy after its entry into WTO must take instruments other than import restrictions into account.

While this study is concerned with a single country and event, the potential for substitution between instruments of trade policy is relevant well beyond China's WTO accession. As early as 1984, Baldwin suggested in the first Handbook of International Economics that nontariff barriers "have been used more extensively by governments to attain the protectionist goals formerly achieved with tariffs." Since then, a handful of other empirical studies have found evidence of substitution from import tariffs to other policies in developing countries including India (Bown and Tovar 2011) and Turkey (Limão and Tovar 2011), as well as in the US (Ray and Marvel 1984) and across countries (Bown and Crowley 2014). ${ }^{1}$ However, these studies all consider substitution between import tariffs and other import-side measures (such as anti-dumping duties); the study of substitution between import-side and export-side policies in the same country is an innovation of this study. ${ }^{2}$

In fact, although there is a long theoretical literature on symmetries between import tariffs and export taxes, beginning with Lerner's classic contribution in $1936,{ }^{3}$ very few papers have actually observed an empirical relationship between tariffs and export taxes. ${ }^{4}$

\footnotetext{
${ }^{1}$ See Feinberg and Reynolds (2007), Vandenbussche and Zanardi (2010) and Moore and Zanardi (2011) for other cross-country analyses. Anderson and Schmitt (2003) present a theoretical study of substitution between import-side policies.

${ }^{2}$ Some observers have drawn parallels between cuts in import tariffs in one country and the negotiation of agreements requiring its trading partners to place quotas on exports ('voluntary export restraints', or VERs). See Yu (2000) for a theoretical discussion.

${ }^{3}$ For example, McKinnon (1966) provides an theoretical extension of Lerner symmetry to an economy with intermediate goods.

${ }^{4}$ Golub and Finger (1979) observe a cross-country relationship of this kind, noting parallels between import tariffs on downstream goods in developed countries and export taxes on raw materials in their less
} 
This dearth of empirical papers on a long-studied theoretical topic is partly due to the fact that global data on export taxes is sparse. The assembly of detailed panel data on export restrictions in China, allowing for comparisons with trends in import tariffs, is thus a contribution to this literature. ${ }^{5,6}$

The relationship between the trade policies studied here and the value chain also situates this paper in a literature linking growth in exports of manufactures to advantageous access to raw materials. In particular, parallels with the case of the United States around the turn of the twentieth century, as studied by Wright (1990) and Irwin (2003), are notable. Wright finds that intensive exploitation of a wide range of local resource endowments played an important role in US manufacturing success during this period, while Irwin reaches similar conclusions in a more focused study of the American iron and steel industry. According to Irwin, the rise in US exports of iron and steel around 1900 was driven in part by the exploitation of a large new deposit of iron ore, whose output was kept within the US due to high transportation costs and vertical integration. Like the US at that time, present-day China is a global leader in the production of many raw materials, but my analysis suggests that privileged access to those inputs for Chinese manufacturers has been generated, at least in part, by state-imposed restrictions on their export.

Finally, because of China's size and the importance of its WTO accession to the world economy, studies of the effects of China's WTO entry such as this one are of particular interest to scholars of both economic development and international trade. Existing papers have focused mainly on the effects of tariff cuts on local outcomes (e.g. Chen and Ravallion 2004, Brandt et al. 2012a), rather than their implications for local policies. The apparent presence of policy substitution in China suggests that these and other studies might underestimate the direct effects of China's tariff cuts if they do not take domestic policy responses into account.

The remainder of the paper is laid out as follows. Section 2 provides background information on China's WTO accession, including its commitments regarding import tariffs. Section 3 introduces the export restrictions data and discusses the evolution of Chinese export restrictions over time. Section 4 analyzes the relationship between China's export restrictions and its import tariffs, while Section 5 examines whether export restrictions have actually affected China's export patterns. Section 6 then draws conclusions.

developed trading partners. See also Latina et al. (2011).

${ }^{5}$ This data is available to other researchers on my web site.

${ }^{6}$ In work contemporaneous to this study, Eisenbarth (2014) and Gourdon et al. (2016a) use data on some of the export restrictions studied here to investigate the motivation for these policies, but neither of these papers explores their implications for the effects of import tariffs. The dataset in this paper is also distinctive in that it includes a wider range of policy instruments and years. Chandra and Long (2013) calculate the elasticity of Chinese exports to VAT rebate rates using firm-level data on VAT payments, and Gourdon et al. (2016b) also estimate the effects on exports of China's VAT rebate policy, though neither of these papers examines the indirect effects of upstream policies on downstream exports. Solleder (2013) compiles data on export taxes from twenty countries, including two years of data on export duties in China. 


\section{Background: China and WTO}

After finalizing WTO accession agreements with the United States in 1999 and the European Union in 2000, China entered WTO in December 2001. China already held most-favourednation (MFN) status in each of its main trading partners at the time of its entry into WTO, so the schedule of import tariffs that it faced in these countries did not change after its WTO membership. However, China gained market access abroad through a decline in trade policy uncertainty: perhaps most importantly, China's MFN status in the US was subject to annual renewal before 2001, but was made permanent upon China's accession to WTO. ${ }^{7}$

As a WTO member, China became bound both by WTO rules and by additional specific commitments made as conditions of its accession. Like other countries joining WTO, one of China's key commitments was to permanently set its import tariffs at or below levels agreed in international negotiations. For almost all products, this bound tariff rate was equal to or smaller than China's applied tariff in 1999, the year in which agreement on tariffs on industrial products was reached, and so tariff cuts were required in order to meet this condition. ${ }^{8}$ The schedule for implementation of China's bound tariffs extended to 2010, with most tariffs to be reduced to their bound rates by 2005.

In practice, China's nonagricultural applied tariffs were indeed reduced to their bound levels after its WTO accession. As a consequence, China's mean applied tariff across nonagricultural products decreased from $16 \%$ in 1999 to $9 \%$ in 2012, as shown in Table 1 Panel A. Because negotiated tariff cuts were highly correlated to initial tariff levels (with a correlation coefficient of approximately 0.8 across nonagricultural products), these cuts led to a compression of China's tariff schedule. Panel A of Table 1 accordingly shows that the standard deviation of China's applied tariffs across products declined along with the mean.

Since its accession to WTO, a number of China's policies have been the subject of disputes addressed through the WTO's dispute settlement mechanism. During the period studied in this paper (up to 2012), China was the respondent in 19 separate cases brought by other WTO members. Two of these disputes involved its restrictions on exports: China - Measures related to the exportation of various raw materials (brought to the dispute settlement mechanism by the US, EU and Mexico in 2009) and China - Measures related to the exportation of rare earths, tungsten and molybdenum (brought by the US, EU and Japan in 2012).

The complainants in these two cases portrayed China's export restrictions as important instruments of industrial policy; a US government submission for the 2009 case argued that "China's industrial strategy is to leverage and exploit the differences in the international and

\footnotetext{
${ }^{7}$ Handley and Limão (2013) and Pierce and Schott (2016) find that uncertainty related to the difference between US MFN tariffs and the non-MFN tariffs that would otherwise have prevailed for China has explanatory power for the evolution of US manufacturing employment after 2001.

${ }^{8}$ Throughout the paper, I restrict the analysis to nonagricultural products (or industries), and also omit important agricultural inputs (fertilizers and pesticides); see the data appendix for details. This is because liberalization of trade in agricultural products, where nontariff barriers tend to be particularly important, often involved replacement of nontariff barriers with tariff-based protection during this period rather than tariff cuts (Branstetter and Lardy 2008). The inclusion of agricultural products into the analysis therefore complicates the interpretation of the relationship between export policies and import tariffs in Section 4. Including agricultural products somewhat weakens but does not otherwise change the results in the paper.
} 
Table 1: Summary statistics of Chinese trade policies

\begin{tabular}{|c|c|c|c|}
\hline \multicolumn{4}{|l|}{ Panel A. Import tariffs } \\
\hline Import tariffs & $\begin{array}{l}.161 \\
(.098)\end{array}$ & $\begin{array}{c}.089 \\
(.058)\end{array}$ & $\begin{array}{l}.093 \\
(.060)\end{array}$ \\
\hline \multicolumn{4}{|c|}{ Panel B. Export VAT rebate policies and export duties } \\
\hline $\begin{array}{l}\text { Export tax equivalent of } \\
\text { export VAT rebate policies }\end{array}$ & $\begin{array}{l}.019 \\
(.020)\end{array}$ & $\begin{array}{l}.057 \\
(.040)\end{array}$ & $\begin{array}{l}.063 \\
(.063)\end{array}$ \\
\hline Export duties & $\begin{array}{l}.002 \\
(.023)\end{array}$ & $\begin{array}{l}.004 \\
(.026)\end{array}$ & $\begin{array}{l}.007 \\
(.036)\end{array}$ \\
\hline Joint export tax equivalent & $\begin{array}{l}.021 \\
(.033)\end{array}$ & $\begin{array}{l}.063 \\
(.063)\end{array}$ & $\begin{array}{l}.073 \\
(.093)\end{array}$ \\
\hline \multicolumn{4}{|c|}{ Panel C. Export processing prohibitions } \\
\hline Export processing prohibitions & .0003 & .062 & .158 \\
\hline \multicolumn{4}{|c|}{ Panel D. Other export restrictions } \\
\hline & 2002 & 2007 & 2012 \\
\hline Export licenses & .020 & .039 & .042 \\
\hline Export quotas & .019 & .014 & .017 \\
\hline State or designated trading & .008 & .007 & .007 \\
\hline Any of the above & .022 & .041 & .043 \\
\hline
\end{tabular}

domestic markets for raw materials and downstream, processed products, using restraints on exports as the linchpin" (WTO 2011). However, China argued that its policies were covered by Article XX of the General Agreement on Tariffs and Trade, which allows for exceptions from GATT/WTO rules for measures "relating to the conservation of exhaustible natural resources" or "necessary to protect human, animal or plant life or health". In both cases, WTO panels ruled that the policies identified by the complainants were inconsistent with China's WTO accession commitments. In response to the rulings, China altered some of its export policies specific to the narrow range of products identified in the cases, starting in 2013. However, most of China's export restrictions were not targeted by these disputes and therefore remained in place. ${ }^{9}$

\footnotetext{
${ }^{9}$ The disputes targeted export duties, export licenses and export quotas on raw materials for which
} 


\section{Export restrictions in China}

In this section, I document the proliferation of export restrictions in China after its accession to WTO. Specifically, I consider each of the instruments identified by the WTO Trade Policy Reviews of China (WTO 2006, 2008, 2010, 2012) as 'policies affecting exports' for which product-level schedules are available. ${ }^{10}$ The analysis below covers the period up to 2012 , since after this time, China altered some of these policies in response to rulings by WTO panels, as discussed above. ${ }^{11}$ The key findings of this section are that variation in export restrictions across nonagricultural products rose steadily after China's WTO accession, and that changes in Chinese export policies appear to have been coordinated across several different instruments.

I begin by discussing China's value-added tax (VAT) rebates for exporters. As noted by Feldstein and Krugman (1990), in an international system where countries charge VAT on imports (as do China and other countries with value-added taxes), the nondistortionary policy is for countries to also fully rebate VAT on exports, so that the effective VAT rates charged on domestically produced and imported goods are equalized within each country. This means that incomplete rebates of VAT constitute a tax on exports. However, in China, the official VAT rebate rates for Chinese exporters, which are set at the product level, are often lower than the rate of VAT charged (which is $17 \%$ for most nonagricultural goods).

I have therefore gathered product-level panel data on Chinese VAT rates and export VAT rebate rates. The data is taken from policy updates that are periodically disseminated to firms in electronic format from official sources and used to calculate and apply for tax rebates. The set of these updates starting from 2004 is available from the web site www.taxrefund.com.cn, and data for 2003 were found at www.cnnsr.com. To this I add product-level data for 2002 from the 2001-2002 Export Commodity Code and Tax Rebate Rate Quick Reference Handbook (State Administration of Taxation 2002).

Figure 2 plots the distribution of export VAT rebate rates for nonagricultural products in 2002, 2007 and 2012. ${ }^{12}$ It is apparent from the figure that the dispersion of VAT rebate rates across products increased greatly over this period. Moreover, while in 2002, exporters of most products received full or near-full rebates, approximately $20 \%$ of products were subject

China's share of world production was large, so the export restrictions removed by China were likely of disproportionate importance to its trade policy regime. The role of such products in China's export policies will be discussed further in Section 4.

${ }^{10}$ One such instrument is export prohibitions (see data appendix); however, there are only a small number of products whose export was entirely prohibited by China at any time during the period studied, and I simply exclude these products from the empirical analysis. Also, some policies that are classified as 'policies affecting exports' in the WTO reviews but that do not vary primarily at the product level, such as tax concessions to foreign-invested enterprises, are not considered here.

${ }^{11}$ However, because these changes left most of China's export restrictions untouched, the empirical results below change very little when the sample period is extended.

${ }^{12}$ These policies are generally set at either the eight-digit or the ten-digit product level, and the Chinese product classification changes from year to year. I therefore weight each observation according to the level of aggregation at which the rebate is defined, such that each six-digit product is weighted equally according to a six-digit product classification that is consistent over time. 
2002

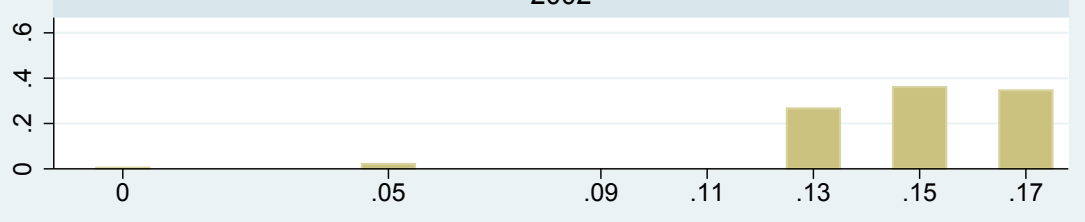

2007
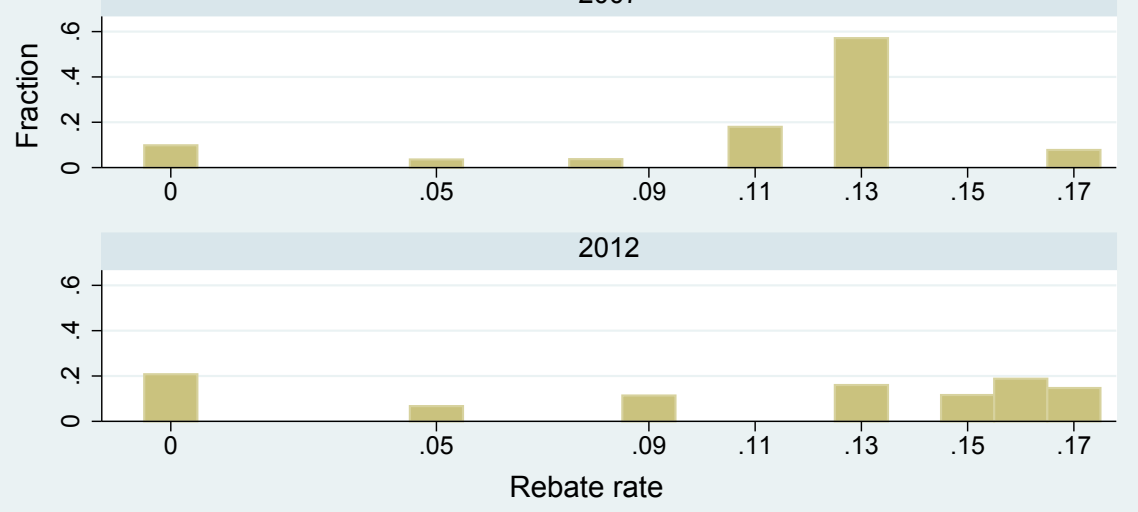

Figure 2: Distribution of China's export VAT rebates across nonagricultural products, 2002, 2007 and 2012

to a zero-rebate policy by 2012 .

These policy changes did not simply serve to restore a pattern of export restrictions dating from before 2002. Although I do not have product-level data on export VAT rebate policies before 2002, more aggregate summaries of pre-2002 policy changes are available from the China Master Tax Guide published by Deloitte Touche Tomatsu (2005). Using this information, I extrapolate the 2002 product-level data back to 1994, the year in which VAT was first placed at the center of China's taxation system. I then use the data to calculate export tax equivalents of China's export VAT rebate policies for each product and year between 1994 and 2012 (see data appendix for details), and summarize the evolution of these export taxes in Figure 3.

As shown in the figure, there were many changes to China's export rebate policies over this period. At the time of China's taxation reform in 1994, a policy of full export VAT rebates for most nonagricultural goods was maintained. However, the widespread practice of claiming rebates for goods that were not actually exported resulted in excessive fiscal obligations for the central government, and official rebate rates were significantly reduced soon afterwards (Branstetter and Lardy 2008). This led to a steep rise in the average export tax equivalent of rebate policies, but because this cut in rebates applied across the board, variation in export taxes across products did not rise accordingly. Rebate rates were raised again in the late 1990s - at the time of the negative export demand shock associated with the Asian financial crisis - and China's export VAT rebate policy was then relatively stable until 2003.

However, an official notice in October 2003, less than two years after China's WTO ac- 


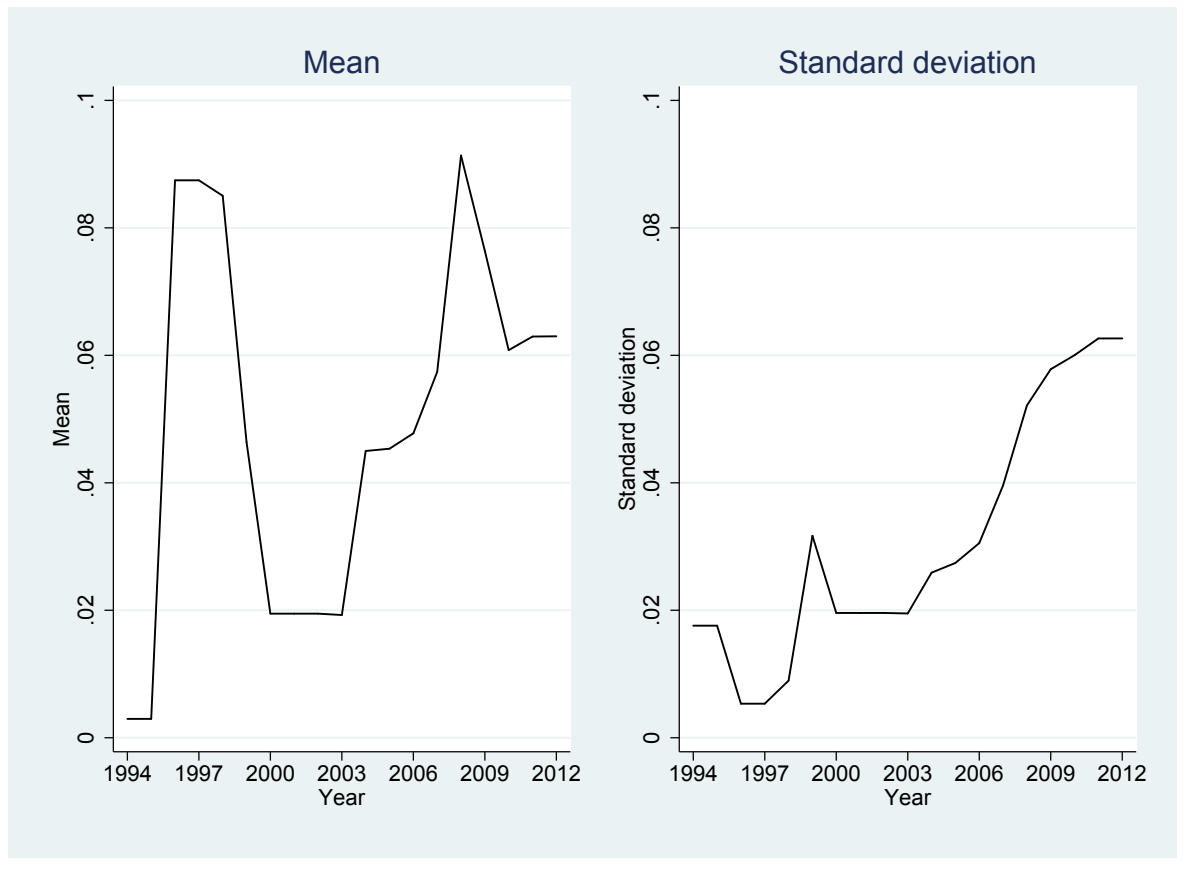

Figure 3: Mean and standard deviation of export tax equivalents of China's export VAT rebate policies across nonagricultural products, 1994 to 2012

cession, announced a significant reform of rebate rates to be effective in January $2004 .{ }^{13}$ This was the first in a series of notices frequently amending China's export rebate rates over the following several years. Figure 3 shows that these policy changes usually increased the average export tax equivalent of VAT rebate policies, but at the time of the late-2000s global recession, instead served to support exports through decreases in mean export taxes. However, unlike the pre-2002 policy changes, the 2003 notice and subsequent reforms consistently increased the variation in export taxes across products. Table 1 Panel B shows that the standard deviation of these export taxes rose from $2.0 \%$ in 2002 to $4.0 \%$ in 2007 and $6.3 \%$ in 2012 .

Because VAT rebates for exporters are bounded below at zero, the export tax equivalent of this policy instrument is bounded above at the rate of VAT (see data appendix for details). But in addition to charging export taxes via incomplete rebates of VAT to exporters, China also directly imposes duties on some exported products. While neither export duties nor incomplete VAT rebates for exporters are prohibited under WTO rules, China's WTO accession agreement allows for export duties only on a small group of products, ruling out such duties on other goods "except under exceptional circumstances" (WTO 2001). Until 2004, China's schedule of export duties only included a subset of the goods identified in its accession agreement. However, starting in 2005, China began imposing 'temporary' export duties on some other products, and the number of products covered by these duties continued

${ }^{13}$ Caizheng bu, guojia shuiwu zongju caishui (2003) no. 222. 


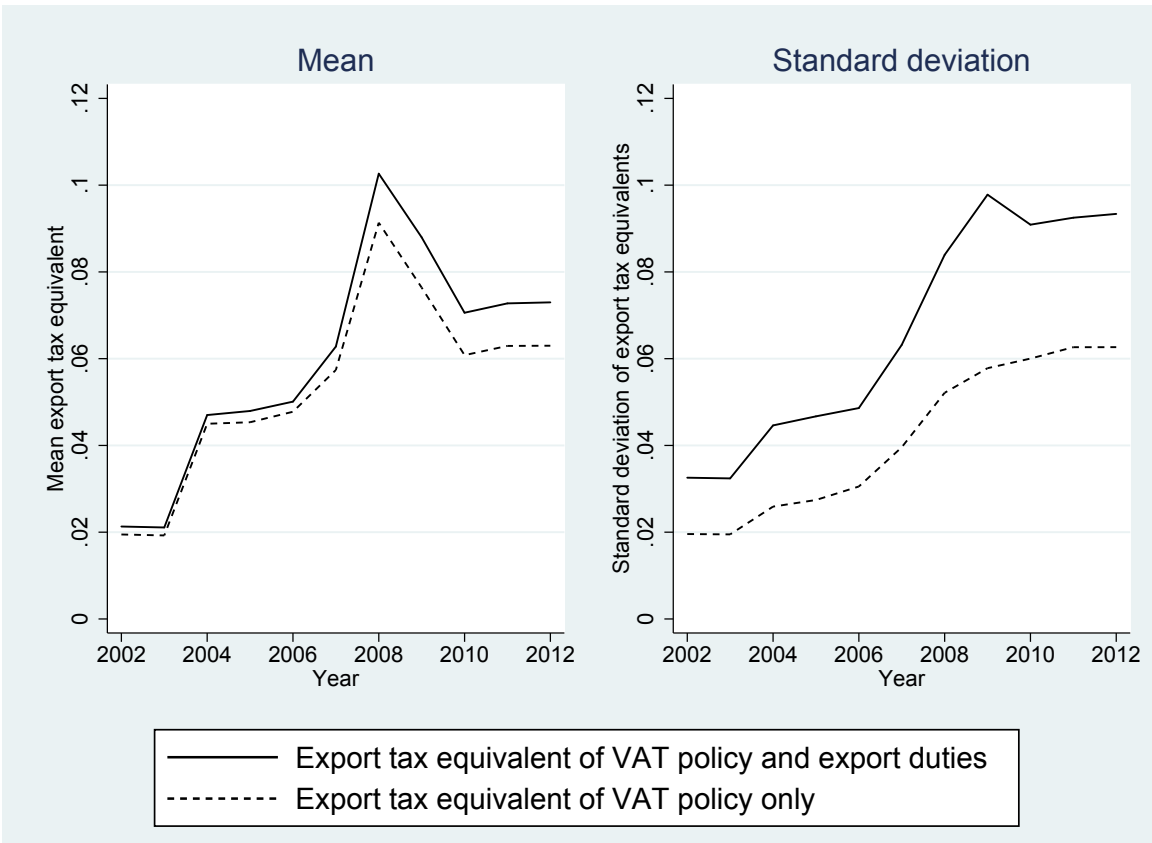

Figure 4: Mean and standard deviation of export tax equivalents of China's export VAT rebate policies and export duties across nonagricultural products, 2002 to 2012

to rise thereafter.

The lists of goods subject to export duties and the corresponding rates are published by China annually together with its schedule of import tariffs in the Customs Import and Export Tariff of the People's Republic of China, and I have collected product-level data on export duties from this publication for the years 1997 to 2012. According to this data, export duties have affected only a narrow range of goods: the share of six-digit products with a nonzero export duty was just $0.7 \%$ as of 2002 , rising to $3.3 \%$ in 2007 and $5.1 \%$ by $2012 .{ }^{14}$ However, these duties have become increasingly coordinated with China's export VAT rebate policies over time. Before 2005, export duties were mostly imposed on goods whose exporters were eligible for nonzero rebates of VAT. But by 2012, export duties were imposed exclusively on products whose export VAT rebate rates were zero; i.e. products whose export taxes via VAT rebate policy were at their maximum possible level.

Thus, although they have been quite sparingly applied, Figure 4 shows that rising export duties have made an important additional contribution to the increasing variation in export taxes across products since China's WTO accession. The figure compares export taxes resulting from export VAT rebate policies to the joint export tax equivalent of both export duties and export VAT rebate policies (see the data appendix for details), for the years 2002 to 2012. Inclusive of both instruments, the standard deviation across nonagricultural goods of China's export taxes rose from $3.3 \%$ to $9.3 \%$ between these two years, as shown in Table

\footnotetext{
${ }^{14}$ More precisely, this is the share of six-digit products within which at least one eight-digit product had a nonzero export duty in these years.
} 


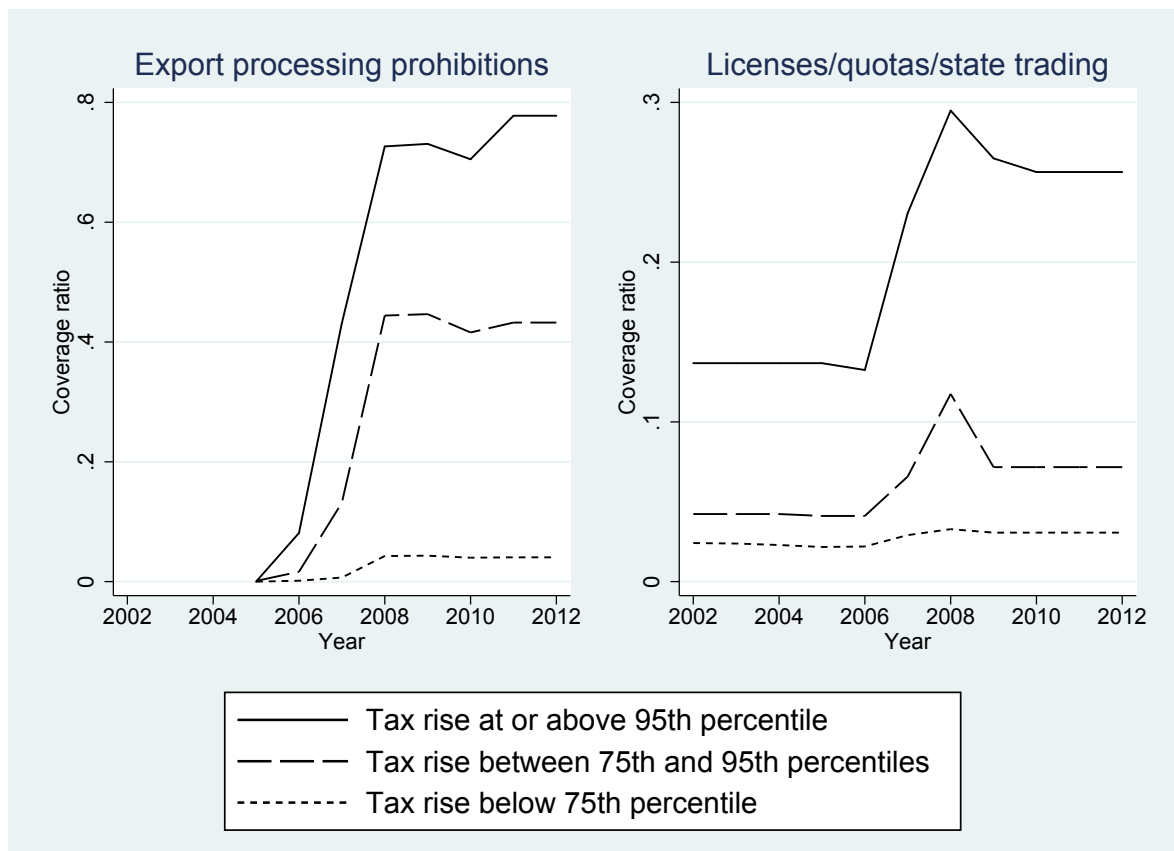

Figure 5: Product-level coordination between export tax rises between 2002 and 2012 and changes in other export policies

1 Panel B. The major role played by export duties in this rise occurred despite the fact that these duties had a much smaller effect on mean export taxes across products during this period.

These two policy instruments cover only products exported from China under the system of 'ordinary trade'. However, during the period studied, approximately half of Chinese exports by value left the country via 'processing trade', a system by which inputs from abroad may be imported duty-free, processed and then re-exported, again duty-free. I have thus also collected information on product-level changes in China's processing trade policy regime. Specifically, I observe a series of ad hoc official notices updating the list of products prohibited from export via processing trade, beginning with a 2004 notice declaring that "[a]djustments and updates will be made annually to the list of prohibited processing trade goods ... in accordance with the country's economic development and industrial policies." 15 As can be seen in Panel $\mathrm{C}$ of Table 1, the share of six-digit nonagricultural products affected by processing trade prohibitions rose from less than $0.1 \%$ in 2005 to $6.2 \%$ in 2007 and $15.8 \%$ in $2012 .^{16}$

To check whether these changes in processing trade eligibility have been coordinated with rises in the joint export tax equivalent of the two instruments discussed above, I tabulate

\footnotetext{
${ }^{15}$ Shangwu bu, haiguan zongshu, guojia huanjing baohu zongju gonggao (2004) no. 55. In practice, subsequent updates were not announced on a strictly annual basis. See the data appendix for details.

${ }^{16}$ Specifically, this is the proportion of six-digit products within which at least one ten-digit product was prohibited from export via processing trade in these years.
} 
increases in the incidence of processing trade prohibitions for products in different quantiles of export tax growth. Specifically, I calculate the increase in the export tax between 2002 and 2012 for each six-digit product, separate products into three groups according to the size of this export tax increase, and then chart the evolution of the share of each group of products that are covered by an export processing prohibition over time. The results, displayed in Figure 5, provide clear evidence of coordination of export policies affecting ordinary and processing trade. ${ }^{17}$ While only a miniscule proportion of products in each quantile was prohibited from export via processing trade as of 2002 , this share had risen to $78 \%$ for goods in the top $5 \%$ of post-accession export tax increases, $43 \%$ for the next $20 \%$ and $4 \%$ for the bottom $75 \%$ of products by 2012 .

Finally, I consider other restrictions on exports, by sourcing data on the set of products requiring export licenses or subject to export quotas, and goods which may only be exported by designated (usually state-owned) firms, from the annual official notices relating to these measures for 2002 to 2012. ${ }^{18}$ These policies were to be phased out for some products as conditions of WTO accession, and indeed, the share of six-digit products subject to at least one of these restrictions fell from $2.3 \%$ in 2002 to $2.1 \%$ in 2005 . However, this share then increased to $4.1 \%$ by 2007 and remained at approximately this level thereafter; as of 2012, this proportion was $4.3 \%$. As shown in Panel D of Table 1, this was mostly due to a rise in the share of products requiring export licenses.

Moreover, the evolution of these policies also appears to be related to post-accession changes in export taxes. As shown in Figure 5, among six-digit products whose export tax increase between 2002 and 2012 was in the top 5\%, the share of goods subject to license requirements, quotas or state trading increased from $14 \%$ in 2002 to $25 \%$ in 2012 . The other products in the top quartile of export tax rises saw a rise in the coverage ratio of these policies from $4 \%$ to $7 \%$, while only $3 \%$ of the bottom three quartiles were covered by such an export restriction in 2012, a rise of one percentage point from 2002.

\section{Export restrictions and the pattern of protection}

In this section, I consider the extent to which the changes in China's export policies documented above can be interpreted as a continuation of its pre-WTO trade policy. To do so, I relate the growth in Chinese export restrictions after China's WTO accession to its pattern of import restrictions across industries before accession. I then consider a closely related question: whether changes in export restrictions partly offset the cuts in import tariffs that were required of China as a condition of its WTO accession. I find that China's post-accession export policy changes are strongly related to both its pre-WTO tariffs and its tariff cuts.

\footnotetext{
${ }^{17}$ In practice, product-level changes in VAT rebate policies and processing trade eligibility have sometimes been made in the same official notice.

${ }^{18}$ I gather data only for unilateral policy measures; export quotas related to the multilateral Multifiber Arrangement are thus not included here. See the data appendix for details.
} 


\subsection{Trade policy before and after WTO accession: simple correlations}

I begin by estimating specifications motivated by a simplified analysis that - for now - abstracts from indirect effects via input-output relationships between industries. First note that variation in either import restrictions or export restrictions across industries should serve to stimulate production in some of these industries at the expense of others, although the specific firms and products affected by either policy may differ. In other words, the use of either trade policy instrument generates a pattern of protection across industries. Next consider the direct effect of each instrument: for import restrictions on an industry's products, this is to protect the industry from import competition, while the direct effect of an export restriction on the goods produced by an industry is to discourage their export. If China's post-accession export policies have evolved in accordance with its pre-WTO industrial policy priorities, we would therefore expect its pre-WTO import restrictions and post-accession export restrictions to be negatively related at the industry level. ${ }^{19}$ To see this more clearly, note that industries with relatively lower export taxes may equivalently be seen as industries with relatively higher export subsidies, which, like higher import tariffs, are trade policies favouring those industries.

I therefore first examine whether the changes in China's export policies after WTO accession are negatively related to its pre-WTO pattern of import protection across industries, as defined by its schedule of import tariffs in 1999. I use China's 1999 tariffs because this was the final tariff schedule released by China before agreement was reached on the nonagricultural tariff cuts required for its WTO accession; however, the results below are robust to using other base years. Throughout the section, I focus mainly on the joint export tax equivalent of China's export VAT rebate policies and its export duties, but also sometimes show results for other instruments. ${ }^{20}$ I conduct the analysis mainly at the level of the fourdigit industry according to the Chinese industrial classification, clustering standard errors by two-digit industry. ${ }^{21}$

Figure 6 summarizes how the relationship between China's export taxes and 1999 tariffs has evolved over time, by plotting the estimated coefficients $\hat{\beta}^{t}$ from a series of simple regression specifications:

$$
\operatorname{exporttax}_{i}^{t}=\alpha^{t}+\beta^{t} \text { tariff } f_{i}^{1999}+\epsilon_{i}^{t}
$$

I run the regression in equation (1) for each year $t$ between 1997 and 2012. The figure shows that as the variation in export taxes gradually rose after China's WTO accession (see Figure 4 ), it also increasingly reflected the variation in China's pre-accession import tariffs.

\footnotetext{
${ }^{19}$ See the theory appendix for a more careful discussion of this point. Note that this is not a statement about the economywide effect of trade barriers - i.e. the stimulation or discouragement of trade across all industries - since this also depends on the average height of those barriers.

${ }^{20}$ Like export VAT rebates and duties on exports, the import tariffs considered here were incident on goods imported via ordinary trade rather than processing trade.

${ }^{21}$ An example of a four-digit industry is 'Manufacture of glass apparatus', which lies within the two-digit category 'Manufacture of non-metal products'.
} 


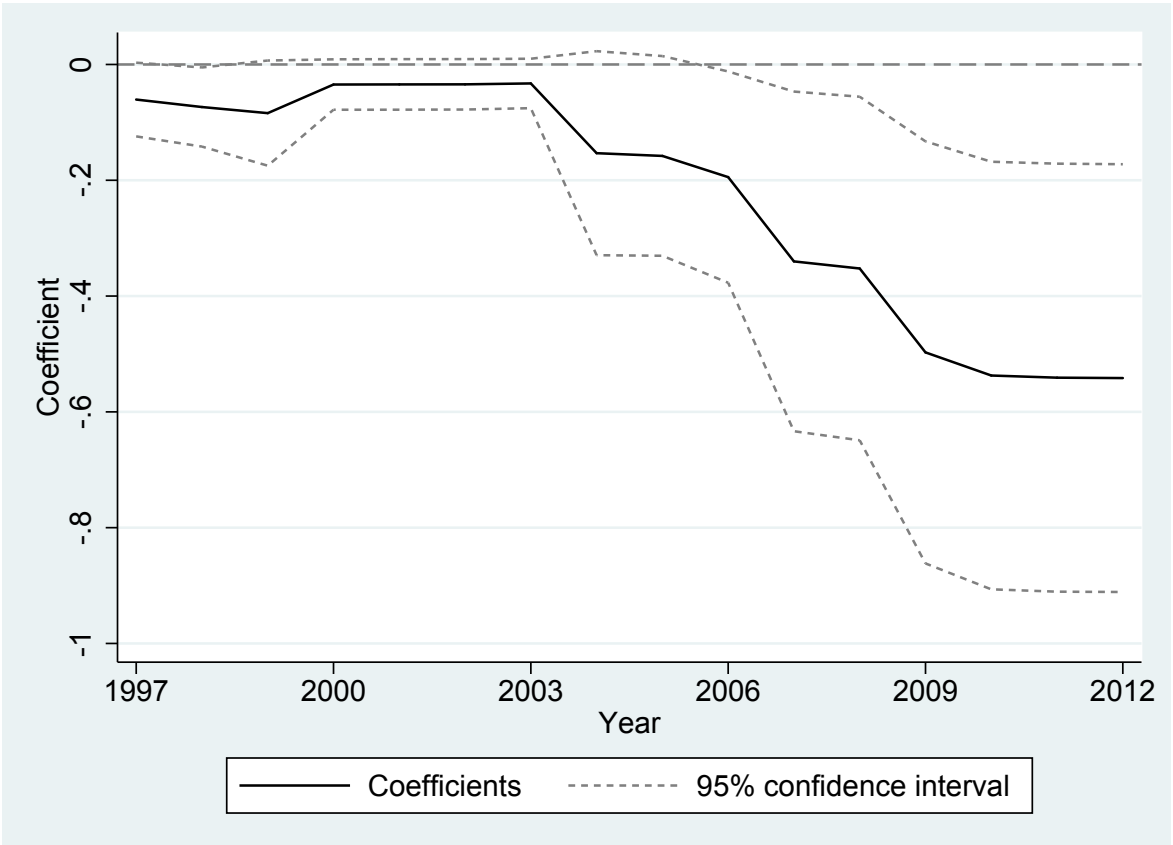

Figure 6: Coefficients of annual industry-level regressions of export tax equivalents of China's export VAT rebate policies and export duties on 1999 applied tariffs, 1997 to 2012

Column (1) of Table 2 displays the results of a simple regression of $\Delta \operatorname{exporttax}_{i} \equiv$ $\operatorname{exporttax}_{i}^{2012}-$ exporttax $_{i}^{2002}$ on tariff ${ }_{i}^{1999}$. This shows that across four-digit industries, a one percentage point larger 1999 tariff is associated with a one-half percentage point smaller rise in export taxes from 2002 to 2012 . The estimate is statistically significant at the $1 \%$ level, using p-values derived from wild bootstraps as in Cameron et al. (2008) due to the small number of clusters.

In Table 3, I separately consider the links between 1999 tariffs and each of the export policy instruments discussed in the previous section. Columns (1) and (2) of Table 3 show that the result in column (1) of Table 2 is due to both China's export VAT rebate policies and its export duties, since the changes in each instrument are related to China's pre-accession tariffs. Specifically, a one point higher tariff in 1999 is associated with a 0.3 point lower rise in the export tax equivalent of China's VAT rebate policies, and a 0.14 point smaller increase in export duties, between 2002 and 2012. ${ }^{22}$ Over the same period, increases in the share of products covered by export processing prohibitions are also systematically related to 1999 tariffs at the industry level (column (3) of Table 3). However, despite their apparent coordination with other export-side instruments (as documented in the previous section), there is no evidence that post-accession changes in other export restrictions are related to China's pre-WTO import tariffs (see column (4)).

${ }^{22}$ The estimated coefficient in column (1) of Table 2 is larger than the total of these two estimates because the joint export tax equivalent of the two instruments generally exceeds the sum of the export tax equivalents of each instrument calculated separately; see the data appendix for details. 
Table 2: Changes in export taxes and pre-WTO import tariffs

\begin{tabular}{|c|c|c|c|c|c|c|c|}
\hline \multirow{2}{*}{$\begin{array}{l}\text { Dependent variable: } \\
\text { Unit of observation: }\end{array}$} & \multicolumn{6}{|c|}{$\Delta$ Export tax } & \multirow{2}{*}{$\begin{array}{c}\Delta \text { ERP } \\
\text { via taxes } \\
(7) \\
\text { I/O } \\
\text { sector }\end{array}$} \\
\hline & $\begin{array}{c}(1) \\
\text { 4-digit } \\
\text { industry }\end{array}$ & $\begin{array}{c}(2) \\
\text { 2-digit } \\
\text { industry }\end{array}$ & $\begin{array}{c}(3) \\
\text { 4-digit } \\
\text { industry }\end{array}$ & $\begin{array}{c}(4) \\
\text { 6-digit } \\
\text { product }\end{array}$ & $\begin{array}{c}(5) \\
\text { 4-digit } \\
\text { industry }\end{array}$ & $\begin{array}{c}(6) \\
\text { 4-digit } \\
\text { industry }\end{array}$ & \\
\hline Tariff 1999 & $\begin{array}{c}-.51 \\
(.17) \\
{[.004]}\end{array}$ & $\begin{array}{c}-1.04 \\
(.17) \\
{[.002]}\end{array}$ & $\begin{array}{c}-.44 \\
(.16) \\
{[.014]}\end{array}$ & $\begin{array}{c}-.33 \\
(.08) \\
{[.000]}\end{array}$ & $\begin{array}{l}-.48 \\
(.17) \\
{[.01]}\end{array}$ & $\begin{array}{r}-.001 \\
(.02) \\
{[.99]}\end{array}$ & \\
\hline Import NTB & & & & & $\begin{array}{l}-.04 \\
(.02) \\
{[.11]}\end{array}$ & & \\
\hline $\begin{array}{l}\text { Raw materials } \\
\text { industry }\end{array}$ & & & & & & $\begin{array}{c}.22 \\
(.03) \\
{[.000]}\end{array}$ & \\
\hline $\begin{array}{l}\text { Tariff } 1999 \\
\text { * raw materials }\end{array}$ & & & & & & $\begin{array}{l}-.91 \\
(.18) \\
{[.002]}\end{array}$ & \\
\hline ERP via tariffs 1999 & & & & & & & $\begin{array}{l}.50 \\
(.15) \\
{[.001]}\end{array}$ \\
\hline Observations & 402 & 35 & 211 & 1,118 & 402 & 402 & 71 \\
\hline Clusters & 35 & 35 & 29 & 70 & 35 & 35 & 71 \\
\hline$R^{2}$ & .25 & .65 & .18 & .18 & .26 & .62 & .22 \\
\hline
\end{tabular}

Columns (1) to (4) display the results of regressions of changes in the joint export tax equivalent of China's export VAT rebate policies and its export duties between 2002 and 2012 on China's 1999 applied tariffs. Column (5) adds the share of products for which China's WTO accession agreement specifies that non-tariff barriers to imports were to be removed as an independent variable. Column (6) adds a dummy for raw materials industries and its interaction with 1999 tariffs as independent variables. Column (7) shows the results of a regression of the difference in effective rates of protection (ERP) between the 2002 and 2012 schedules of Chinese export taxes on the ERPs due to China's 1999 tariff schedule. See the text for details of changes in the construction of the variables and the sample in columns (3) and (4). The unit of observation is a four-digit industry in columns (1), (3), (5) and (6), a two-digit industry in column (2), a six-digit product in column (4) and an input-output sector in column (7). All regressions are estimated using ordinary least squares. Robust standard errors (in round brackets) are clustered at the two-digit industry level in columns (1), (2), (3), (5) and (6), at the two-digit product level in column (4) and at the input-output sector level in column (7). p-values are in square brackets; these are derived from wild bootstraps as in Cameron et al. (2008) in columns $(1),(2),(3),(5)$ and (6) because of the small number of clusters. 
Table 3: Changes in export restrictions and pre-WTO tariffs by instrument

\begin{tabular}{lcccc}
\hline Dependent variable: & $\begin{array}{c}(1) \\
\Delta \text { Export tax } \\
\text { via VAT policy }\end{array}$ & $\begin{array}{c}(2) \\
\text { Export } \\
\text { duty }\end{array}$ & $\begin{array}{c}\Delta \text { Export } \\
\text { processing ban }\end{array}$ & $\begin{array}{c}\Delta \text { Other } \\
\text { restriction }\end{array}$ \\
\hline Tariff 1999 & -.30 & -.14 & -.85 & .06 \\
& $(.10)$ & $(.05)$ & $(.41)$ & $(.35)$ \\
Observations & {$[.006]$} & {$[.002]$} & {$[.04]$} & {$[1.00]$} \\
Clusters & 402 & 402 & 402 & 402 \\
$R^{2}$ & 35 & 35 & 35 & 35 \\
\hline
\end{tabular}

This table displays the results of regressions of changes in Chinese export restrictions between 2002 and 2012 on China's 1999 import tariffs. The export restrictions are defined as follows: in column (1), the export tax equivalent of China's export VAT rebate policies; in column (2), export duties; in column (3), the share of products covered by an export processing prohibition; in column (4), the share of products requiring an export license, subject to an export quota or which may only be exported by designated firms. The unit of observation is a four-digit industry. Robust standard errors (in round brackets) are clustered at the two-digit industry level. pvalues are in square brackets; these are derived from wild bootstraps (as in Cameron et al. 2008) because of the small number of clusters.

It is important to note that the simple analysis motivating these regressions depends on the existence of intra-industry trade; i.e. that China both imports and exports products within an industry. If China instead exclusively imports goods in some industries and exports in others, then the logic underlying the regressions above breaks down, since a relatively high import tariff and a relatively low export tax cannot directly benefit the same industry. Below, I expand the analysis to allow for indirect effects via input-output relationships, but I first estimate three additional simple specifications motivated by this issue. First, I aggregate to the level of the two-digit industry, at which intra-industry trade is more relevant, and consider the relationship between 1999 import tariffs and post-accession rises in export taxes at this level. Column (2) of Table 2 shows that at the two-digit level, the relationship between 1999 tariffs and changes in export taxes remains negative and significant, and is now approximately one-to-one.

I next return to the four-digit industry level, but change how the two policy variables are defined. For the regressions above, I have calculated industry-level tax and tariff rates by taking a simple average across all products in each industry. For each industry, I now instead average import tariffs across products of which China was a net importer in 1999, and average export taxes across products of which China was a net exporter in 1999. This means that different sets of products within each industry are used for the calculation of each of the two policy variables. Industries for which China was a net exporter or net importer of all products in 1999 are therefore dropped from the analysis. This exercise nonetheless still includes 211 industries, and yields similar results to the baseline regression, as shown in column (3) of Table 2. 
Finally, I run a regression at the product level, including only products of which China was both an importer and an exporter in 1999. Specifically, the sample consists of the 1,118 products for which the share of Chinese exports in the total value of Chinese imports and exports was between $25 \%$ and $75 \%$ in 1999. Column (4) of Table 2 suggests that the relationship of interest is qualitatively unchanged by this strategy.

A related issue is that goods subject to high post-accession export taxes might be traded much less intensively than the goods on which pre-WTO tariffs were imposed. I therefore examine whether China's 2012 export taxes and 1999 import tariffs were incident on trade flows of similar size. To do this, I multiply China's 2012 exports and imports (by value) by 2012 export taxes and 1999 tariffs respectively, and find that estimated 2012 export tax revenue is $34 \%$ of what tariff revenue would have been if 1999 tariffs applied to 2012 trade flows. ${ }^{23}$ Since export taxes have a negative effect on export volumes (as shown in Section 5), I also repeat the same exercise using trade flows from 1999 instead of 2012, and find that the counterfactual export tax revenue is $40 \%$ of estimated 1999 import tariff revenue. Finally, I note that the simple average across six-digit nonagricultural products of China's 2012 export taxes (7.3\%) is $44 \%$ of the simple average of its 1999 import tariffs $(16.1 \%)$. This back-of-the-envelope exercise therefore suggests that post-accession export taxes apply to trade flows of comparable size to those on which pre-WTO import tariffs, if restored in 2012, would be incident. ${ }^{24}$

The regressions above have focused only on import tariffs rather than non-tariff barriers to imports, but China's pre-WTO import policy regime included both types of instruments. While I do not observe all of China's pre-WTO non-tariff import restrictions, China's WTO accession agreement included a list of products for which non-tariff barriers to imports were to be removed. Treating this list as a proxy for the full set of 1999 non-tariff import restrictions, I add the share of products included in this list in each industry to the baseline regression as a second right-hand-side variable. The results, in column (5) of Table 2, suggest that both 1999 import tariffs and 1999 non-tariff barriers are independently related to subsequent changes in Chinese export taxes, although the p-value for the latter result is slightly above 0.1 .

\subsection{Trade policy and input-output relationships}

So far, I have shown that changes in China's export policies after its WTO accession are systematically related to its pre-accession import policies at the level of the industry. I next progress from the simple analysis above by exploring the interaction of these policies with input-output relationships between industries. As discussed in the introduction, the symmetry between import tariffs and export taxes has been known since Lerner (1936). But in practice, the input-output matrix complicates this symmetry to the extent that Grossman and Horn (2013) have suggested that it is "not a practical possibility" to fully replicate a

\footnotetext{
${ }^{23}$ I first deduct export taxes due to VAT policy from reported Chinese exports by value, so as to avoid double-counting.

${ }^{24}$ Note that this calculation does not take account of the fact that these policies are generally inapplicable to goods imported or exported via processing trade.
} 
given set of import tariffs with a well-chosen regime of export taxes. This is due to the fact that a trade policy directly incident on one industry should have larger indirect effects on industries closer to it in the value chain. However, in practice, due to the large number of traded goods in each industry and their complex (and imperfectly measured) input-output relationships, it is unrealistic to expect that these indirect effects can be fully modelled.

Nonetheless, it may be possible to replicate key elements of a given pattern of protection through relatively simple policy initiatives. Across countries and time, the most prominent relationship between trade policy and the value chain is the widespread phenomenon of 'tariff escalation', in which tariffs on downstream goods are systematically higher than those on upstream products. ${ }^{25}$ In other words, trade policy worldwide has tended to favour industries producing goods for final consumption over those producing raw materials. In the theory appendix, I present a simple model showing the mechanisms by which import tariffs on downstream industries and export taxes on raw materials could each achieve such a pattern of protection. ${ }^{26}$ The theory shows that upstream export taxes favour downstream sectors both by directly discouraging upstream production, and by pushing the domestic price of raw materials below the world price, supporting downstream industries by providing them with an input cost advantage.

Table 4 shows that variation in trade policy by stage of production is highly relevant to the context studied here. It displays the results of regressions of 1999 tariffs and changes in export taxes from 2002 to 2012 on indicators for whether a four-digit industry is a producer of primary raw materials, semiprocessed raw materials, or capital goods; the omitted category is industries producing consumer goods. ${ }^{27}$ Column (1) shows that on average, China's 1999 applied tariffs were 8 percentage points lower for semiprocessed raw materials industries and 19 percentage points lower for primary industries as compared to tariffs for industries producing products for final consumption. Export tax rises, on the other hand, have varied in the opposite way with the value chain: these are 7 points higher for the semiprocessed stage and 22 points higher for the primary stage on average relative to industries producing consumer goods. Moreover, approximately one-third of variation in 1999 tariffs and one-half of variation in export tax rises, as measured by $R^{2}$, is explained via this simple model of the value chain. It should be noted that the inverse relationship between the two policies is not present for capital goods industries; although these industries had relatively lower pre-WTO import tariffs than those of sectors producing consumer goods, export taxes on capital-producing and other final goods industries both remained relatively low after 2002 .

These results suggest that much of the strong industry-level relationship between export tax rises and 1999 tariffs is due to the simple fact that both policies tend to favour industries further downstream. However, there is also variation in Chinese export tax increases across industries within stages of production. Most of this variation is between upstream industries:

\footnotetext{
${ }^{25}$ See Balassa (1965) and Cadot et al. (2004) for empirical evidence on tariff escalation covering two different time periods.

${ }^{26}$ The model also suggests a reason why countries might prefer to impose downstream import tariffs rather than upstream export taxes if both options are available.

${ }^{27}$ I classify industries into these categories using the United Nations Broad Economic Categories (BEC) product classification; see the data appendix for details.
} 
Table 4: Changes in export restrictions and pre-WTO tariffs by stage of production

\begin{tabular}{lcc}
\hline & $(1)$ & $(2)$ \\
Dependent variable: & Tariff 1999 & $\Delta$ Export tax \\
\hline Primary & -.19 & .22 \\
raw materials & $(.02)$ & $.03)$ \\
& {$[.002]$} & {$[.000]$} \\
Semiprocessed & -.08 & .07 \\
raw materials & $(.02)$ & $(.02)$ \\
& {$[.004]$} & {$[.000]$} \\
Capital goods & -.08 & -.01 \\
industry & $(.01)$ & $. .01)$ \\
& {$[.002]$} & {$[.43]$} \\
Observations & 402 & 402 \\
Clusters & 35 & 35 \\
$R^{2}$ & .31 & .52 \\
\hline
\end{tabular}

The dependent variable in column (1) is China's 1999 applied tariffs, and in column (2) it is the difference between 2012 and 2002 export taxes. Both regressions include dummies for primary raw materials industries, semiprocessed raw materials industries and capital goods industries. The omitted category is other downstream industries. The unit of observation is a four-digit industry. Both regressions are estimated using ordinary least squares. Robust standard errors (in round brackets) are clustered at the 2-digit industry level. p-values are in square brackets; these are derived from wild bootstraps (as in Cameron et al. 2008) because of the small number of clusters.

while the average rise in export taxes from 2002 to 2012 for downstream industries was 1.5\% with a standard deviation of $2.7 \%$, the corresponding mean and standard deviation across raw materials industries was $12.0 \%$ and $11.1 \%$ respectively. In order to examine how this variation relates to China's pre-WTO tariff schedule, I estimate the following augmented version of the baseline regression specification, including 1999 tariffs, a dummy for industries producing primary or semiprocessed raw materials, and an interaction term:

$$
\left.\Delta \text { exporttax }_{i}=\alpha+\text { Btariff }_{i}^{1999}+\text { rrawmaterials }_{i}+\theta \text { (tariff }_{i}^{1999} * \text { rawmaterial }_{i}\right)+\epsilon_{i}
$$

The results of this regression, in column (6) of Table 2, further demonstrate the relative simplicity of China's post-WTO export policy. In particular, $62 \%$ of the variation across industries in export tax increases is explained by two factors: the asymmetric incidence of export tax rises across stages of production, and a nearly one-to-one relationship between initial tariffs and subsequent changes in export taxes across raw materials industries. Meanwhile, the much more limited variation in export policy changes across downstream industries is unrelated to China's pre-WTO tariff schedule. 
The indirect effects of China's export taxes, via input-output relationships between industries, thus theoretically reinforce its pre-WTO pattern of protection through two channels. First, as mentioned above, by imposing upstream export taxes, an exporter of raw materials can generate a wedge between their domestic and world prices, supporting domestic downstream firms by giving them an input cost advantage. Through this channel, China's export taxes support downstream industries in general, which were also systematically favoured by China's pre-accession import tariffs.

Second, the specific downstream industries that received greater protection through lower import tariffs on raw materials inputs in 1999 have subsequently been supported through larger increases in export taxes on inputs from the same industries. In other words, privileged access to domestic inputs has been increased by more (via higher upstream export taxes) for downstream industries that also faced relatively lower 1999 tariffs on imported inputs. This channel operates only for industries that use both imported and domestic raw materials from the same upstream industry as inputs into production. ${ }^{28}$

Both of these theoretical channels are only empirically relevant if export restrictions have been imposed on raw materials of which China is a relatively important world producer; otherwise, these policies would have little effect because they would not substantially change the relative domestic and world prices of those products. Using international trade data for 2012 from UN COMTRADE, I therefore calculate the share of Chinese exports in the total value of world trade for each product. I find that among the six-digit nonagricultural products for which China's 2012 export taxes are greater than or equal to 10\% (which encompasses approximately $25 \%$ of these goods), Chinese exports constitute more than $10 \%$ of world trade for one third. Among raw materials products above the $10 \%$ export tax threshold, China's exports exceed $10 \%$ of total world trade in $31 \%$ of cases. Indeed, according to the British Geological Survey (2010), China was the world's leading producer in at least 37 categories of minerals and metals as of 2008, in 12 of which it produced more than half of total world output. China is thus a large player in world trade for a wide variety of the products on which it has placed high export taxes, despite the negative impact of these taxes on export volumes (which is examined in Section 5). ${ }^{29}$

\footnotetext{
${ }^{28} \mathrm{~A}$ third possible channel could be that export taxes rose most steeply on inputs to the downstream industries with the highest pre-WTO tariffs. The evidence for this hypothesis is, however, relatively weak, and is thus not shown here.

${ }^{29}$ This raises the question of whether China's export restrictions are related to potential terms-of-trade gains. For example, export taxes on rare earth elements might be designed to exploit China's near-monopoly on global rare earths production. In the case of rare earths, the Vice Chairman of China's Inner Mongolia province suggested otherwise in a 2009 press conference: "We are certainly not focusing on the short-term benefits of raising the rare earth price. Our wish is for Baotou in Inner Mongolia to become the world's 'Rare Earths Valley', the world's rare earths industrial base" (china.com.cn 2009). More generally, the product-level relationship between export tax rises and China's share of world trade is positive but small in magnitude and weak. This is true for specifications including China's 2002 share of world trade and for regressions instrumenting China's 2012 share of world trade with its 2002 share, regardless of whether these specifications use across-industry or within-industry policy variation; results are available on request. The results of Table 2 are unchanged when China's share of world trade, specified in either way, is included. Note finally that if policies motivated by terms-of-trade considerations are systematically related to characteristics of individual goods that make demand for them relatively inelastic, such as product differentiation (as in
} 
Finally, I jointly summarize both the direct and indirect relationships between export tax increases and 1999 tariffs, using the effective rate of protection (ERP) as defined by Corden (1966). This is a simple measure of the protection resulting from trade policies incident on both an industry itself and its inputs. I use China's 2002 input-output table to calculate the ERPs resulting from China's 1999 tariff schedule, as well as the changes in ERPs due to changes in export taxes between 2002 and 2012. ${ }^{30}$ Column (7) of Table 2 shows that when the latter variable is regressed on the former at the input-output sector level, a statistically significant relationship is again observed. In particular, if the ERP due to import tariffs was one percentage point higher for an input-output sector in 1999, then it experienced a larger rise in the ERP via export taxes of one-half percentage point from 2002 to 2012. Note, however, that while this estimate neatly encapsulates the full relationship between the two policies in principle, it should be treated with some caution in practice, as individual Chinese input-output sectors often aggregate a wide range of industries (e.g. 'Mining of non-ferrous metal ores') and sometimes include multiple stages of production (e.g. paper pulp, paper and paper products).

\subsection{Offsetting changes in trade policies}

The results above show that after China's flexibility to impose import restrictions was restricted by WTO accession, its export restrictions evolved to resemble its pre-accession pattern of tariff protection. However, recall from Section 2 that across products, China's negotiated tariff cuts were highly correlated to its 1999 tariff levels. China's export policy changes therefore also partly offset the effects of the tariff cuts required by its accession agreement. ${ }^{31}$

To measure the extent to which this has been the case, Table 5 reproduces the results of Table 2, but with the difference between China's bound tariffs and its 1999 tariffs as the key independent variable in columns (1) to (6). ${ }^{32}$ Both the magnitudes of the estimated coefficients and their p-values are similar to those in Table 2, and indeed indicate the partial offset of tariff cuts by rises in export taxes. The results in column (7) suggest that across input-output sectors, a one percentage point decline in ERP via tariff cuts is associated on average with a two-thirds percentage point rise in the ERP due to changes in export taxes.

Broda et al. 2008), we would expect China's post-accession export taxes and pre-accession import tariffs to be positively rather than negatively related across products. However, this is not the case, either across or within industries.

${ }^{30}$ See the data appendix for details of my calculations of ERPs.

${ }^{31}$ Notably, such an outcome was predicted in a 2002 Journal of International Economics article by Branstetter and Feenstra, who stated that "interviews of expatriate managers in China strongly indicate that these individuals believe tariff cuts will be at least partially undone by the simultaneous construction of more subtle non-tariff barriers".

${ }^{32}$ I reassign bound tariff rates to be equal to 1999 tariffs whenever tariff bindings actually exceed China's applied tariffs in 1999. Because there are very few cases where this is true, this adjustment makes little difference to the results. 
Table 5: Changes in export taxes and tariff cuts required by WTO accession

\begin{tabular}{|c|c|c|c|c|c|c|c|}
\hline \multirow{2}{*}{$\begin{array}{l}\text { Dependent variable: } \\
\text { Unit of observation: }\end{array}$} & \multicolumn{6}{|c|}{$\Delta$ Export tax } & \multirow{2}{*}{$\begin{array}{c}\Delta \text { ERP } \\
\text { via taxes } \\
(7) \\
\text { I/O } \\
\text { sector }\end{array}$} \\
\hline & $\begin{array}{c}(1) \\
\text { 4-digit } \\
\text { industry }\end{array}$ & $\begin{array}{c}(2) \\
\text { 2-digit } \\
\text { industry }\end{array}$ & $\begin{array}{c}(3) \\
\text { 4-digit } \\
\text { industry }\end{array}$ & $\begin{array}{c}(4) \\
6 \text {-digit } \\
\text { product }\end{array}$ & $\begin{array}{c}(5) \\
\text { 4-digit } \\
\text { industry }\end{array}$ & $\begin{array}{c}(6) \\
\text { 4-digit } \\
\text { industry }\end{array}$ & \\
\hline $\begin{array}{l}\Delta \text { Tariff due to } \\
\text { WTO accession }\end{array}$ & $\begin{array}{c}.66 \\
(.20) \\
{[.002]}\end{array}$ & $\begin{array}{l}1.40 \\
(.30) \\
{[.006]}\end{array}$ & $\begin{array}{c}.53 \\
(.18) \\
{[.012]}\end{array}$ & $\begin{array}{c}.37 \\
(.08) \\
{[.000]}\end{array}$ & $\begin{array}{c}.60 \\
(.20) \\
{[.004]}\end{array}$ & $\begin{array}{l}.08 \\
(.06) \\
.26]\end{array}$ & \\
\hline Import NTB & & & & & $\begin{array}{l}.05 \\
(.01) \\
{[.04]}\end{array}$ & & \\
\hline $\begin{array}{l}\text { Raw materials } \\
\text { industry }\end{array}$ & & & & & & $\begin{array}{c}.15 \\
(.03) \\
{[.000]}\end{array}$ & \\
\hline $\begin{array}{l}\Delta \text { Tariff } \\
* \text { raw materials }\end{array}$ & & & & & & $\begin{array}{l}1.00 \\
(.31) \\
{[.006]}\end{array}$ & \\
\hline$\Delta \mathrm{ERP}$ via tariffs & & & & & & & $\begin{array}{l}-.67 \\
(.17) \\
{[.000]}\end{array}$ \\
\hline Observations & 402 & 35 & 211 & 1,118 & 402 & 402 & 71 \\
\hline Clusters & 35 & 35 & 29 & 70 & 35 & 35 & 71 \\
\hline$R^{2}$ & .17 & .48 & .12 & .14 & .19 & .50 & .17 \\
\hline
\end{tabular}

Columns (1) to (4) display the results of regressions of changes in the joint export tax equivalent of China's export VAT rebate policies and its export duties between 2002 and 2012 on the difference between China's bound tariffs and its 1999 applied tariffs. Column (5) adds the share of products for which China's WTO accession agreement specifies that non-tariff barriers to imports were to be removed as an independent variable. Column (6) adds a dummy for raw materials industries and its interaction with the difference between bound and 1999 applied tariffs as independent variables. Column (7) shows the results of a regression of the difference in effective rates of protection (ERP) between the 2002 and 2012 schedules of Chinese export taxes on the change in ERPs between China's 1999 tariff schedule and its schedule of bound tariffs. See the text for details of changes in the construction of the variables and the sample in columns (3) and (4). The unit of observation is a four-digit industry in columns (1), (3), (5) and (6), a two-digit industry in column (2), a six-digit product in column (4) and an input-output sector in column (7). All regressions are estimated using ordinary least squares. Robust standard errors (in round brackets) are clustered at the two-digit industry level in columns (1), (2), (3), (5) and (6), at the two-digit product level in column (4) and at the input-output sector level in column (7). p-values are in square brackets; these are derived from wild bootstraps as in Cameron et al. (2008) in columns (1), (2), (3), (5) and (6) because of the small number of clusters. 


\section{$5 \quad$ Export restrictions and exports}

In practice, the argument that China's export restrictions have partly restored its pre-WTO pattern of industrial protection also relies on two additional assumptions that have not yet been discussed. The first is that export restrictions imposed by the Chinese government have actually influenced economic outcomes. The second is that other changes in China's industrial policy during this period - which I do not observe - have not offset the effects of the export policies discussed above. If both of these assumptions hold, we should observe that trends in Chinese exports after WTO accession track the evolution of its export restrictions. In particular, we should expect a negative relationship between export taxes on a product and exports of that product, but a positive relationship between upstream export taxes and exports of downstream products. In this section, I examine the evidence for these hypotheses, and also check whether industries subject to larger export restrictions sell a greater share of their output on the domestic market. As shown below, I find that all of these correlations are present in the data.

I first use panel trade data by six-digit product $p$ (in section $s$ of the Harmonized System product classification) and year $t$ to estimate the following specification:

$$
\ln \text { exports }_{p s t}=\alpha+\beta \text { exporttax }_{p s t}+\beta^{U} \text { exporttax }_{p s t}^{\text {upstream }}+\theta_{p}+\phi_{s t}+X_{p s t}^{\prime} \eta+\epsilon_{p s t}
$$

The sample covers 2002 to 2012, the period over which my data on export restrictions is observed at the product level. An export tax is defined as the joint export tax equivalent of China's export VAT rebate policies and its export duties; some specifications also separately include the other export restrictions discussed above. All regressions include product and section-year fixed effects. This means that the results are based on a comparison of productlevel trends in exports within each of the sections of the HS product classification, such as chemicals ('Products of the Chemical and Allied Industries') or metals ('Base Metals and Articles of Base Metal'). ${ }^{33}$ All specifications also include a set of additional variables $X_{p s t}$, including import tariffs, upstream import tariffs and the logarithm of the value of world trade by product and year. The hypotheses of interest are that $\beta<0$ and $\beta^{U}>0$, though I will conservatively present $\mathrm{p}$-values based on two-sided tests. ${ }^{34}$

A key challenge in the estimation of this specification is to define input-output relationships between products. I use two different measures of upstream taxes and tariffs. I first calculate these based on information on sector-level input usage from China's 2002 input-

\footnotetext{
${ }^{33} \mathrm{As}$ in the previous sections, agricultural products and agricultural inputs are excluded from the sample. Also, because the end of the Multifiber Arrangement presumably had a significant impact on textiles and apparel exports during this period, I additionally drop all products in section 11 of the HS product classification (which covers textiles and apparel). After these adjustments, twelve HS sections (out of a total of 21) are represented in the sample.

${ }^{34}$ Note also that because the left-hand-side variable is the logarithm of export value, observations with zero trade flows are dropped, and so the coefficients should be interpreted as pertaining to the intensive margin of trade. Since Chinese exports are equal to zero in fewer than $3 \%$ of the product-year observations in the sample, this is a reasonable specification here. Trade flow data is from UN COMTRADE (see data appendix for details).
} 
output table. However, because the products in the sample span only 69 broadly defined input-output sectors, this information is quite coarse, as discussed in the previous section.

I thus also define input-output linkages between goods using a different source: information on materials usage embodied in the Harmonized System product classification. In particular, I identify all nonagricultural primary raw materials in the HS classification (such as 'copper ores and concentrates'), and then find all other (nonprimary) HS products for which at least one of these raw materials is mentioned in the product description (such as 'copper springs'). For this, I use both the English-language descriptions of six-digit products and Chinese-language descriptions of products at the more detailed eight-digit level to identify six-digit goods containing these materials; further details may be found in the data appendix.

This results in a total of 42 raw materials for which both primary and nonprimary products can be found. The sample consists of the nonprimary products, for each of which I define the upstream export tax (or import tariff) as the export tax (or import tariff) on the primary raw material with which the good is associated. For the regressions below, I keep only nonprimary products linked to exactly one material, so that I can cluster all standard errors by primary raw material. This leaves a total of 588 products in the sample, mostly semiprocessed raw materials.

I present the results of estimating specification (3) in columns (1) and (6) of Table 6. In column (1), I use the input-output table to calculate upstream taxes and tariffs, while in column (6) I use HS product descriptions. The estimated coefficients on export taxes are negative, statistically significant and of a similar magnitude in both cases. ${ }^{35}$ The estimated coefficient in column (1) indicates that a rise in export taxes of one percentage point is associated with a 5.10 percentage point decline in the value of Chinese exports, while the analogous estimate in column (6) is -7.46 .

The estimated coefficients on upstream export taxes in columns (1) and (6) are also both of the predicted sign, although they differ greatly in magnitude. Using data from China's 2002 input-output table, a one percentage point increase in upstream export taxes is associated with a rise in exports of 6.99 percentage points, and this estimate is statistically significant at the $1 \%$ level. Meanwhile, using data from HS descriptions, the estimated magnitude of the relationship is much smaller (0.59) but remains significant at the $5 \%$ level. ${ }^{36}$

The difference between the two estimates is not due to the narrower sample used in column (6). When the regression in column (1) is re-estimated with the sample from column (6), the estimated coefficient on upstream export taxes is similar to the estimate in column (1); see column (2) of Table 6. Instead, it is simply the case that the two sets of variables reflect different measures of upstream policy. While the HS descriptions variable is based

\footnotetext{
${ }^{35}$ These estimates are in line with the large estimated effects of incomplete export VAT rebates on exports found in two other studies, Chandra and Long (2013) and Gourdon et al. (2016b). Neither of these studies looks at indirect effects via upstream policies.

${ }^{36}$ The estimated relationship between upstream import tariffs and exports (not shown in the table but available upon request) is negative as expected in both columns (1) and (6), although very imprecisely estimated, and the estimate in column (6) is again of much smaller magnitude.
} 


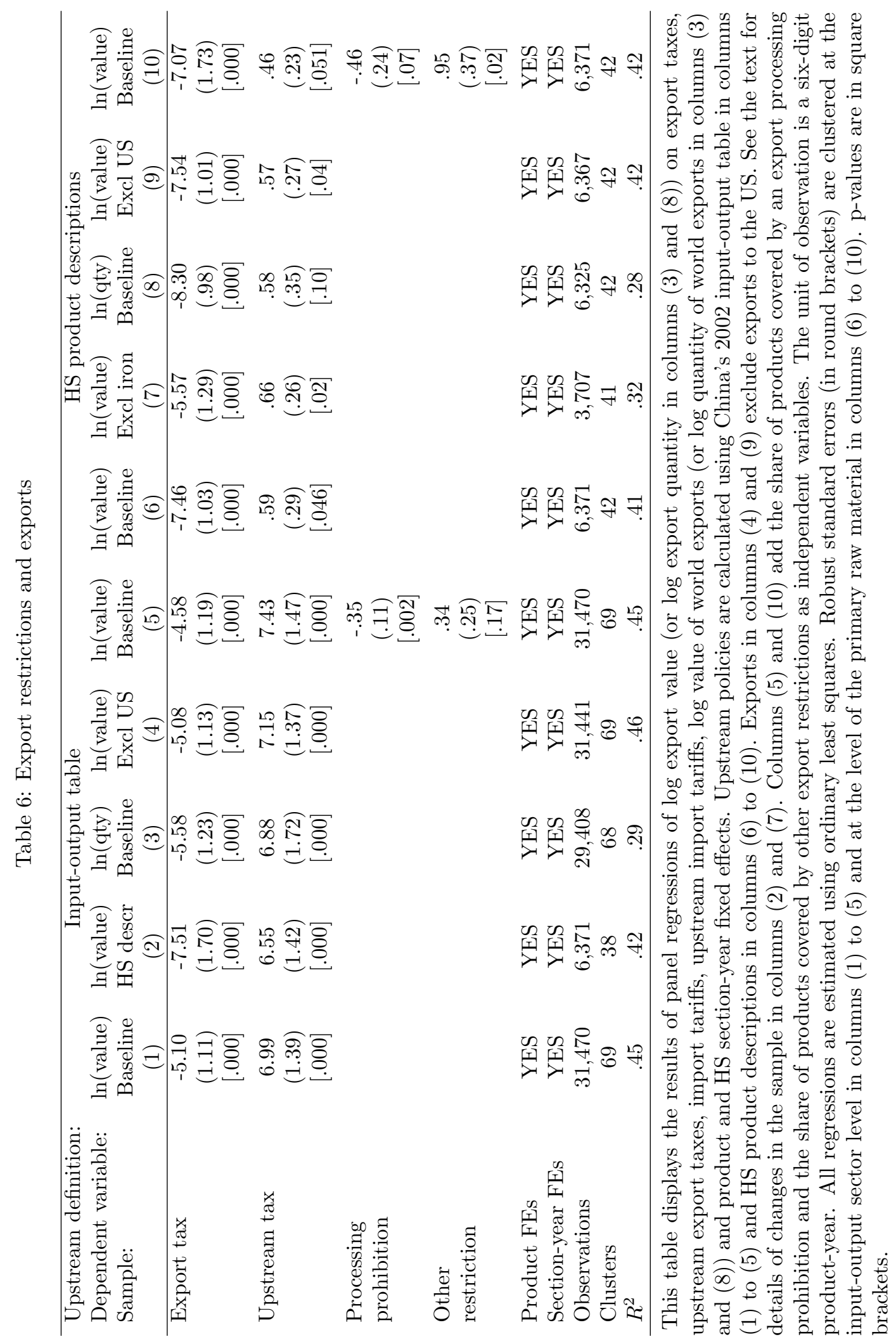


only on primary raw materials, for which rises in China's export taxes have been particularly high, the input-output measure is diminished by the inclusion of other intermediate inputs subject to much lower export taxes. It is thus unsurprising that the estimated effect of upstream export taxes in column (1) is larger in magnitude.

One issue with the data based on HS product descriptions is that a large proportion $(41 \%)$ of products in the sample are linked to a single primary raw material, iron ore. This is due to the detailed subdivision of iron and steel products in the HS classification. In column (7), I thus rerun specification (3), but dropping all products of this raw material. This does not substantially change the coefficient estimates or standard errors.

Since export taxes are likely to directly affect the prices of both exports and downstream exports, in columns (3) and (8) I run the baseline specification using log export quantity instead of log export value. This makes little difference to the estimated coefficients of interest. $^{37}$ I next address the possibility that these trends are driven by changes in trade policy uncertainty in the US, which also vary by product and which Feng et al. (2016) have found have predictive power for Chinese exports, by excluding Chinese exports to the US from the dependent variable. As shown in columns (4) and (9), this strategy also yields very similar coefficient estimates.

Finally, I return to the original specification but add indicator variables for other exportside policies - prohibition of exports via processing trade, and the incidence of either an export license requirement, export quota or state trading requirement - to the right-hand side. Columns (5) and (10) of Table 6 show that the coefficients on the export tax variables are not substantially affected by this new specification, while the estimated coefficient on export processing prohibitions is negative and statistically significant as expected. However, the incidence of other export policies is positively associated with exports, and this relationship is statistically significant in column (10), suggesting that the imposition of these policies may be endogenous to expected export growth.

If export taxes on raw materials are actually effective through the mechanisms discussed in the previous section - i.e. by changing the relative levels of access to these inputs for firms in China and abroad - then we should also observe a diversion of sales of local raw materials to the domestic market. I thus also examine whether industries subject to larger rises in export restrictions have experienced steeper falls in the share of exports in total sales. To do this, I draw upon industry-level tabulations of China's annual firm-level survey of industrial production, which I have for the years 2002 to $2007 .^{38}$ I use reported sales by value and export value (both in current Renminbi) from the survey data to calculate the proportion of exports to foreign markets in firms' sales in each industry and year. I then run a panel

\footnotetext{
${ }^{37}$ Also, while it is important to account for trends in world demand that are unrelated to China, the control for world export value is potentially endogenous because Chinese exports often form a substantial share of total world trade. I thus estimate a specification without this control, in which I instead use China's $\log$ share of world trade as the left-hand-side variable. This also results in little change to either of the coefficients of interest; results are available upon request.

${ }^{38}$ This data, collected by China's National Bureau of Statistics, includes all non-state industrial firms with sales above five million Renminbi and all state-owned industrial firms. As before, I omit textiles and apparel industries from the sample. See the data appendix for details.
} 
Table 7: Export restrictions and share of exports in total sales

\begin{tabular}{lccc}
\hline Dependent variable: & \multicolumn{3}{c}{ Share of exports in total sales } \\
& $(1)$ & $(2)$ & $(3)$ \\
Sample: & All industries & Raw materials & All industries \\
\hline Export tax & -.27 & -.22 & -.22 \\
& $(.07)$ & $(.04)$ & $(.08)$ \\
& {$[.07]$} & {$[.054]$} & {$[.22]$} \\
Processing & & & -.04 \\
prohibition & & & $(.01)$ \\
& & & {$[.04]$} \\
Other & & & .02 \\
restriction & & & $(.04)$ \\
& & & {$[.59]$} \\
Industry FEs & YES & YES & YES \\
Year FEs & YES & YES & YES \\
Observations & 1,908 & 810 & 1,908 \\
Clusters & 30 & 26 & 30 \\
$R^{2}$ & .05 & .11 & .06 \\
\hline
\end{tabular}

This table displays the results of panel regressions of the share of exports in sales on export taxes, import tariffs and industry and year fixed effects. The unit of observation is a four-digit industry. Columns (1) and (3) display the results of regressions including the entire sample of industries, while column (2) displays the results of a regression including only raw materials industries. Column (3) adds the share of products covered by an export processing prohibition and the share of products covered by other export restrictions as independent variables. Robust standard errors (in round brackets) are clustered at the two-digit industry level. p-values are in square brackets; these are derived from wild bootstraps (as in Cameron et al. 2008) because of the small number of clusters.

regression of the export share of sales on export taxes, controlling for import tariffs as well as year and industry fixed effects.

The results of this regression are displayed in Table 7. As shown in column (1), I find that during this period, the estimated impact of a one percentage point increase in export taxes is to decrease the share of exports in total sales by 0.27 percentage points; this result is statistically significant at the $10 \%$ level. ${ }^{39}$ I next check whether this result holds when the sample is restricted to raw materials industries. Column (2) confirms that the estimated coefficient remains of similar magnitude and statistical significance. Finally, in column (3), I add other export restrictions to the specification, again using the full sample of industries, and find that a higher share of products prohibited from export via processing trade is

\footnotetext{
${ }^{39}$ While the estimated effect of tariffs is insignificantly different from zero, its sign is negative. This is consistent with the prediction that higher import tariffs stimulate domestic sales, thus increasing the denominator of the left-hand-side variable. This result is not shown in the table, but is available upon request.
} 
associated with a lower share of exports in total sales, while the coefficient estimate for other export restrictions is insignificantly different from zero. The estimated coefficient on export taxes remains similar, but is now less precisely estimated.

These results provide suggestive evidence that China's export restrictions have had actual effects on exports, and that these have not been offset by other policies, and therefore strengthen the conclusions of Section 4. However, I characterize this evidence as suggestive because changes in other Chinese trade and industrial policies during the post-accession period might also have advantaged the industries protected by China before its WTO accession, and thus contributed to export growth in these industries. For example, post-accession trade disputes over China's support to its automotive industry - the industry with the highest Chinese tariffs in 1999 - have highlighted the existence of tax breaks, grants and loans for Chinese firms meeting export performance criteria.

\section{Conclusion}

In this paper, I have studied the persistence of trade policy in China after its 2001 entry into the World Trade Organization. While the conditions of its WTO accession required China to make cuts to its import tariffs that led to heterogeneous reductions in protection across sectors, I have documented the recent emergence of export restrictions that are likely to have partly restored China's pre-WTO pattern of industrial protection. China's export restrictions are mainly incident on raw materials, and I have observed that larger rises in these export restrictions after WTO accession have been associated with greater downstream export growth.

As discussed at the end of the previous section, this study considers information on only two dimensions of China's trade policy regime: its restrictions on imports and exports. While I have suggested that the collection of comprehensive data on Chinese export restrictions constitutes a useful contribution, this data tells only part of the story. Recent changes to a wide variety of other industry-specific policies, such as domestic content requirements and preferential loans, have likely also substantially altered China's post-accession pattern of protection, possibly in the same direction as its restrictions on exports. Similarly, although export restrictions on raw materials have also been adopted in some other countries, ${ }^{40}$ different governments might seek to achieve their trade and industrial policy goals via a wide variety of different policies, of which the restriction of imports or exports represent only two potential candidates.

It is also important to note that this study does not provide any evidence on the deeper reasons behind the adoption of the policies considered here. The similarity between China's

\footnotetext{
${ }^{40}$ For example, a ban on the export of 41 unprocessed minerals from Indonesia became effective in January 2014, and associated regulations set out the extent to which each mineral must be processed in order to be eligible for export. At a G20 meeting soon after the initial enactment of these regulations, Indonesia's Minister of Trade spoke of "...the aspiration to move up trade's value chain, starting from providing raw materials, then processing raw materials into semi-finished and end products in order for developing countries, such as Indonesia, to be able to enjoy the benefit of the added value" (Indonesia Ministry of Trade 2012).
} 
pre-WTO import tariff schedule and the subsequent changes in its export restrictions might be driven by similar motivations, but this is not necessarily the case. What this paper has instead shown is that without detailed information on China's export restrictions, observers might mistakenly overestimate the distance between the pattern of industrial protection in China before and after its WTO accession. This suggests that the full impact of multilateral negotiations in reshaping trade and industrial policy worldwide - irrespective of the motivations underlying these processes - will remain an open question as long as comprehensive information on policy instruments other than import tariffs remains sparse.

\section{References}

[1] Anderson, Simon P. and Nicolas Schmitt (2003). "Nontariff Barriers and Trade Liberalization", Economic Inquiry 41 (1), 80-97.

[2] Armington, Paul S. (1969). "A Theory of Demand for Products Distinguished by Place of Production", International Monetary Fund Staff Papers 16 (1), 159-176.

[3] Bagwell, Kyle and Robert W. Staiger (1999). "An Economic Theory of GATT", American Economic Review 89 (1), 215-248.

[4] Balassa, Bela (1965). "Tariff Protection in Industrial Countries: An Evaluation", Journal of Political Economy 73 (6), 573-594.

[5] Baldwin, Robert E. (1984). "Trade Policies in Developed Countries", in Ronald W. Jones and Peter B. Kenen, eds., Handbook of International Economics Vol. 1, 571-619.

[6] Bown, Chad P. and Meredith A. Crowley (2014). "Emerging Economies, Trade Policy, and Macroeconomic Shocks", Journal of Development Economics 111 (1), 261-273.

[7] Bown, Chad P. and Patricia Tovar (2011). "Trade Liberalization, Antidumping, and Safeguards: Evidence from India's Tariff Reform", Journal of Development Economics 96 (1), 115-125.

[8] Brandt, Loren, Johannes Van Biesebroeck, Luhang Wang and Yifan Zhang (2012a). "WTO Accession and Performance of Chinese Manufacturing Firms", Centre for Economic Policy Research Discussion Paper 9166.

[9] Brandt, Loren, Johannes Van Biesebroeck and Yifan Zhang (2012b). "Creative Accounting or Creative Destruction? Firm-Level Productivity Growth in Chinese Manufacturing", Journal of Development Economics 97 (2), 339-351.

[10] Branstetter, Lee G. and Robert C. Feenstra (2002). "Trade and Foreign Direct Investment in China: A Political Economy Approach", Journal of International Economics 58 (2), 335-358. 
[11] Branstetter, Lee and Nicholas Lardy (2008). "China's Embrace of Globalization", in Loren Brandt and Thomas G. Rawski, eds., China's Great Economic Transformation, New York: Cambridge University Press, 633-682.

[12] British Geological Survey (2010). Mineral Information and Statistics for the BRIC Countries 1999-2008, Keyworth, Nottingham: British Geological Survey.

[13] Broda, Christian, Nuno Limão and David E. Weinstein (2008). "Optimal Tariffs and Market Power: The Evidence", American Economic Review 98 (5), 2032-2065.

[14] Cadot, Olivier, Jaime de Melo and Marcelo Olarreaga (2004). "Lobbying, Counterlobbying, and the Structure of Tariff Protection in Poor and Rich Countries", World Bank Economic Review 18 (3), 345-366.

[15] Caliendo, Lorenzo and Fernando Parro (2015). "Estimates of the Trade and Welfare Effects of NAFTA", Review of Economic Studies 82 (1), 1-44.

[16] Cameron, A. Colin, Jonah B. Gelbach and Douglas L. Miller (2008). "Bootstrap-based Improvements for Inference with Clustered Errors", Review of Economics and Statistics 90 (3), 414-427.

[17] Chan, Alfred (2008). "An Overview of the VAT Export Refund Rules in China", Tax Notes International 49 (2), 159-164.

[18] Chandra, Piyush and Cheryl Long (2013). "VAT Rebates and Export Performance in China: Firm-Level Evidence", Journal of Public Economics 103, 13-22.

[19] Chang, Ha-Joon (2002). Kicking Away the Ladder: Development Strategy in Historical Perspective, London: Anthem Press.

[20] Chen, Shaohua and Martin Ravallion (2004). "Welfare Effects of China's Accession to the World Trade Organization", World Bank Economic Review 18 (1), 29-57.

[21] china.com.cn (2009). "Inner Mongolia Restructuring and Integrating Rare Earths Industry, Planning to Set Up Reserve System to Stabilize Prices", press conference transcript, accessed via stock.hexun.com/2009-09-02/120928664.html.

[22] Corden, W. M. (1966). "The Structure of a Tariff System and the Effective Protective Rate", Journal of Political Economy 74 (3), 221-237.

[23] Deloitte Touche Tomatsu (2005). China Master Tax Guide 2005, The Hague: Kluwer Law International.

[24] di Giovanni, Julian, Andrei A. Levchenko and Jing Zhang (2014). "The Global Welfare Impact of China: Trade Integration and Technological Change", American Economic Journal: Macroeconomics 6 (3), 153-183. 
[25] Eisenbarth, Sabrina (2014). "Is Chinese Trade Policy Motivated by Environmental Concerns? An Empirical Analysis", mimeo.

[26] Ethier, Wilfred J. (2004). "Political Externalities, Nondiscrimination, and a Multilateral World", Review of International Economics 12 (3), 303-320.

[27] Feinberg, Robert M. and Kara M. Reynolds (2007). "Tariff Liberalisation and Increased Administrative Protection: Is There a Quid Pro Quo?", The World Economy 30 (6), 948-961.

[28] Feldstein, Martin S. and Paul R. Krugman (1990). "International Trade Effects of ValueAdded Taxation", in Assaf Razin and Joel Slemrod, eds., Taxation in the Global Economy, University of Chicago Press, 263-282.

[29] Feng, Ling, Zhiyuan Li and Deborah Swenson (2016). "Trade Policy Uncertainty and Exports: Evidence from China's WTO Accession", National Bureau of Economic Research Working Paper 21985.

[30] Golub, Stephen S. and J. M. Finger (1979). "The Processing of Primary Commodities: Effects of Developed-Country Tariff Escalation and Developing-Country Export Taxes", Journal of Political Economy 87 (3), 559-577.

[31] Gourdon, Julien, Stephanie Monjon and Sandra Poncet (2016a). "Trade Policy and Industrial Policy in China: What Motivates Public Authorities to Apply Restrictions on Exports?", China Economic Review 40, 105-120.

[32] Gourdon, Julien, Laura Hering, Stephanie Monjon and Sandra Poncet (2016b). "How Effective are VAT Export Taxes? Evidence from China", mimeo.

[33] Grossman, Gene M. and Elhanan Helpman (1994). "Protection for Sale", American Economic Review 84 (4), 833-850.

[34] Grossman, Gene M. and Henrik Horn (2013). "Why the WTO? An Introduction to the Economics of Trade Agreements", in Henrik Horn and Petros C. Mavroidis, eds., Legal and Economic Principles of World Trade Law, New York: Cambridge University Press, $9-67$.

[35] Handley, Kyle and Nuno Limão (2013). "Policy Uncertainty, Trade and Welfare: Theory and Evidence for China and the U.S.", National Bureau of Economic Research Working Paper 19376.

[36] Indonesia Ministry of Trade (2012). "The First Occasion of G20 Trade Ministerial Meeting: A New Narrative with Critical Notes", press release.

[37] Irwin, Douglas A. (2003). "Explaining America's Surge in Manufactured Exports, 18801913", Review of Economics and Statistics 85 (2), 364-376. 
[38] Latina, Joelle, Roberta Piermartini and Michele Ruta (2011). "Natural Resources and Non-Cooperative Trade Policy", International Economics and Economic Policy 8 (2), 177-196.

[39] Lerner, A. P. (1936). "The Symmetry Between Import and Export Taxes", Economica 3 (11), 306-313.

[40] Limão, Nuno and Patricia Tovar (2011). "Policy Choice: Theory and Evidence from Commitment via International Trade Agreements", Journal of International Economics 85 (2), 186-205.

[41] McKinnon, Ronald I. (1966). "Intermediate Products and Differential Tariffs: A Generalization of Lerner's Symmetry Theorem", Quarterly Journal of Economics 80 (4), 584-615.

[42] Moore, Michael O. and Maurizio Zanardi (2011). "Trade Liberalization and Antidumping: Is There a Substitution Effect?", Review of Development Economics 15 (4), 601-619.

[43] Pierce, Justin R. and Peter K. Schott (2016). "The Surprisingly Swift Decline of U.S. Manufacturing Employment", American Economic Review 106 (7), 1632-1662.

[44] Ray, Edward J. and Howard P. Marvel (1984). "The Pattern of Protection in the Industrialized World", Review of Economics and Statistics 66 (3), 452-458.

[45] Rodrik, Dani (2004). "Industrial Policy for the Twenty-First Century", John F. Kennedy School of Government Faculty Research Working Paper RWP04-047.

[46] State Administration of Taxation, Import and Export Tax Department (2002). 20012002 Export Commodity Code and Tax Rebate Rate Quick Reference Handbook, Dalian: Dalian University of Technology Press.

[47] Solleder, Olga (2013). "Panel Export Taxes (PET) Dataset: New Data on Export Tax Rates", Graduate Institute of International and Development Studies Working Paper 07/2013.

[48] Vandenbussche, Hylke and Maurizio Zanardi (2010). "The Chilling Trade Effects of Antidumping Proliferation", European Economic Review 54 (6), 760-777.

[49] World Trade Organization (2001). Accession of the People's Republic of China.

[50] World Trade Organization (2006). Trade Policy Review: Report by the Secretariat, People's Republic of China.

[51] World Trade Organization (2008). Trade Policy Review: Report by the Secretariat, China.

[52] World Trade Organization (2010). Trade Policy Review: Report by the Secretariat, China. 
[53] World Trade Organization (2011). China - Measures Related to the Exportation of Various Raw Materials: Reports of the Panel.

[54] World Trade Organization (2012). Trade Policy Review: Report by the Secretariat, China.

[55] Wright, Gavin (1990). "The Origins of American Industrial Success, 1879-1940", American Economic Review 80 (4), 651-668.

[56] Yu, Zhihao (2000). "A Model of Substitution of Non-Tariff Barriers for Tariffs", Canadian Journal of Economics 33 (4), 1069-1090.

\section{A1 Data appendix}

\section{A1.1 Import tariffs and non-tariff barriers}

Data for 1997 to 2011 on China's applied import tariffs and data on China's bound tariffs is sourced from the UNCTAD TRAINS and WTO Tariff Analysis Online databases. Data for 2012 on China's applied import tariffs is transcribed from the 2012 volume of the annual official publication Customs Import and Export Tariff of the People's Republic of China. Information on the set of products for which China's accession agreement specifies that nontariff barriers were to be removed is sourced from the documents associated with China's WTO accession available on the WTO web site.

\section{A1.2 Export duties}

Data sources are discussed in the main text. According to Chinese regulations, for a published export duty rate $t_{x}^{p}$ for a product $p$ (hereafter this $p$ is dropped), the tax owing on export sales of that product is calculated according to:

$$
\frac{t_{x}}{t_{x}+1} \cdot \text { exportsales }^{F O B}
$$

Here, the free on board (FOB) price is the price at which goods are sold abroad (i.e. the price of goods after clearing customs). This implies a tax rate of $t_{x}$ on export sales in terms of pre-duty prices.

\section{A1.3 Export VAT rebates}

Data sources are discussed in the main text. For each product and time period, the data specifies a VAT rate, a rebate rate and the type of rebate policy applied to the product. Different policy types imply different calculations of equivalent export taxes based on the associated Chinese regulations (see e.g. Deloitte Touche Tomatsu 2005, Chan 2008). 
First note that firms whose sales are entirely domestic normally pay VAT on value added (at rate $t_{v}^{p}$ for product $p$ ), by paying VAT on sales while claiming credit for the VAT paid on purchases of inputs; i.e. they are charged 'output VAT' while claiming credit for 'input VAT'. This corresponds to the following formula (again omitting $p$ ):

$$
t_{v} \cdot \frac{\text { sales }}{t_{v}+1}-\text { inputVAT }
$$

\section{A1.3.1 Nonzero rebate, not tax-exempt}

Consider a firm which produces the goods it sells abroad, and which exports in a single product category for which the rebate rate $r^{p}$ is not zero. Such a firm may calculate its VAT payable as the difference between output VAT on local sales and input VAT on local purchases as above, plus a third term $d$ :

$$
d=\left(\text { exportsales }{ }^{F O B, p}-\sum_{p^{\prime}} \text { bonded }^{p^{\prime}}\right) \cdot\left(t_{v}^{p}-r^{p}\right)
$$

where bonded $d^{p^{\prime}}$ corresponds to purchases of imported inputs in sector $p^{\prime}$ that do not go through customs, which may be nonzero if the firm participates in processing trade.

Say that the firm does not purchase bonded imports, and that its input purchases may be unambiguously allocated across inputs used for goods sold domestically and inputs used for exported goods. Then the tax applicable on exports is:

$$
\text { exportsales }^{F O B, p} \cdot\left(t_{v}^{p}-r^{p}\right)-\operatorname{inputVAT}
$$

Under the assumption that the nondistortionary policy is a full rebate of VAT on exports, this would imply an export tax bill on a given product with VAT rate $t_{v}$ and rebate rate $r$ of:

$$
\left(t_{v}-r\right) \cdot \text { exportsales }^{F O B}
$$

While the firm's actual tax bill will differ from this depending on its input VAT, the firm may be assumed to take reimbursement of input VAT into account when purchasing inputs; i.e. the reimbursement of input VAT may be considered to be a component of input prices. This implies a tax rate of $\frac{t_{v}-r}{1-\left(t_{v}-r\right)}$ on pre-tax export sales.

Note that if the firm does not produce the goods exported, but instead buys these from another firm for export, then input VAT (here, the amount of VAT paid by the firm producing the goods to be exported) is rebated to this firm according to the prevailing rebate rate, so that it should be the pre-tax rather than the FOB price that is used in the calculation above. I abstract from this distinction by assuming that all exporters are the producers of the goods exported. 


\section{A1.3.2 Zero rebate, not tax-exempt}

Products with a zero rebate rate are treated as products sold domestically, so that the applicable formula for tax payable is:

$$
t_{v} \cdot \frac{\text { sales }}{t_{v}+1}-\text { input } V A T
$$

Again assuming that that the nondistortionary policy is a full rebate of VAT on exports, this implies a tax rate of $t_{v}$ on pre-tax export sales.

\section{A1.3.3 Exempt from taxes}

A small subset of products are classified as 'exempt from taxes', which means that they pay no output VAT on exports, but their input VAT is not reimbursed. I thus model the applicable export tax in this case as equal to exporters' input VAT. I use the 2002 Chinese input-output table, in which I observe pre-tax gross output and input shares, to calculate the rate of implied export tax per unit of pre-tax gross output for a given input-output sector. I then use a concordance between HS products and 2002 Chinese input-output sectors (see below for details of this concordance) to apply these export tax rates to each product in the 'tax-exempt' category. This assumes uniformity of production functions across products within input-output sectors.

The export tax rate per unit of output for a given input-output sector $k$ is thus calculated to be:

$$
\sum_{k^{\prime}} \beta^{k k^{\prime}} \frac{t_{v}^{k^{\prime}}}{1+t_{v}^{k^{\prime}}}
$$

where $\beta^{k k^{\prime}}$ is the observed expenditure share per unit currency of (pre-tax) output of sector $k$ on inputs from sector $k^{\prime}$.

\section{A1.4 Constructing export tax equivalents}

Here, I calculate the export tax rate jointly implied by the two policies above, for each of the three types of export VAT rebate policies.

\section{A1.4.1 Nonzero rebate, not tax-exempt}

The applicable export taxes are:

$$
\frac{t_{x}}{t_{x}+1} \text { exportsales }+\left(t_{v}-r\right) \cdot \text { exportsales }
$$


We may calculate the tax rate on pre-tax export sales using:

$$
\begin{aligned}
& p^{\text {pretax }}=p^{F O B}-\frac{t_{x}}{t_{x}+1} p^{F O B}-\left(t_{v}-r\right) \cdot p^{F O B} \\
& \Longrightarrow p^{F O B}=\left(1-\frac{t_{x}}{t_{x}+1}-\left(t_{v}-r\right)\right)^{-1} p^{\text {pretax }} \\
& \Longrightarrow p^{F O B}=\left(\frac{t_{x}+\left(t_{v}-r\right)+t_{x}\left(t_{v}-r\right)}{1-\left(t_{v}-r\right)-t_{x}\left(t_{v}-r\right)}+1\right) p^{\text {pretax }}
\end{aligned}
$$

So the applicable export tax rate on pre-tax export sales is $\frac{t_{x}+\left(t_{v}-r\right)+t_{x}\left(t_{v}-r\right)}{1-\left(t_{v}-r\right)-t_{x}\left(t_{v}-r\right)}$.

\section{A1.4.2 Zero rebate, not tax-exempt}

The applicable export taxes are:

$$
\frac{t_{x}}{t_{x}+1} \text { exportsales }+\frac{t_{v}}{t_{v}+1} \text { exportsales }
$$

We may calculate the tax rate on pre-tax export sales using:

$$
\begin{gathered}
p^{\text {pretax }}=p^{F O B}-\frac{t_{x}}{t_{x}+1} p^{F O B}-\frac{t_{v}}{t_{v}+1} p^{F O B} \\
\Longrightarrow p^{F O B}=\left(1-\frac{t_{x}}{t_{x}+1}-\frac{t_{v}}{t_{v}+1}\right)^{-1} p^{\text {pretax }} \\
\Longrightarrow p^{F O B}=\left(\frac{t_{x}+t_{v}+2 t_{x} t_{v}}{1-t_{x} t_{v}}+1\right) p^{\text {pretax }}
\end{gathered}
$$

So the applicable export tax rate on pre-tax export sales is $\frac{t_{x}+t_{v}+2 t_{x} t_{v}}{1-t_{x} t_{v}}$.

\section{A1.4.3 Exempt from taxes}

The export tax rate on pre-tax sales due only to non-reimbursement of input VAT may be calculated as:

$$
\begin{gathered}
p^{V A T}=p^{\text {pretax }}+\sum_{k^{\prime}} \beta^{k k^{\prime}} \frac{t_{v}^{k^{\prime}}}{1+t_{v}^{k^{\prime}}} p^{V A T} \\
\Longrightarrow p^{V A T}=\frac{1}{1-\sum_{k^{\prime}} \beta^{k k^{\prime}} \frac{t_{v}^{k^{\prime}}}{1+t_{v}^{k^{\prime}}}} p^{\text {pretax }}
\end{gathered}
$$


Export duties then imply that:

$$
\begin{gathered}
p^{F O B}=p^{V A T}+\frac{t_{x}}{1+t_{x}} p^{F O B} \\
\Longrightarrow p^{F O B}=\left(1-\frac{t_{x}}{t_{x}+1}\right)^{-1}\left(\frac{1}{1-\sum_{k^{\prime}} \beta^{k k^{\prime}} \frac{t_{v}^{k^{\prime}}}{1+t_{v}^{k^{\prime}}}}\right) p^{p r e t a x} \\
\Longrightarrow p^{F O B}=\left(\frac{t_{x}+\sum_{k^{\prime}} \beta^{k k^{\prime}} \frac{t_{v}^{k^{\prime}}}{1+t_{v}^{k^{\prime}}}}{1-\sum_{k^{\prime}} \beta^{k k^{\prime}} \frac{t_{v}^{k^{\prime}}}{1+t_{v}^{k^{\prime}}}}+1\right) p^{p r e t a x} \\
\text { So the applicable export tax rate on pre-tax export sales is } \frac{t_{x}+\sum_{k^{\prime}} \beta^{k k^{\prime}} \frac{t_{v}^{k^{\prime}}}{1+t_{v}^{k^{\prime}}}}{1-\sum_{k^{\prime}} \beta k^{k k^{\prime}} \frac{t_{v}^{k^{\prime}}}{1+t_{v}^{k^{\prime}}}} .
\end{gathered}
$$

\section{A1.5 Prohibitions of exports via processing trade}

Data for 2005 to 2012 on products prohibited from export via processing trade is assembled from the set of ad hoc official notices updating the list of prohibited products; I observe these notices starting in 2004. I define the policies prevailing on January 1 of each year as the data for that year, with the exception of 2008, when I also include major changes to the list of prohibited products that took effect in mid-January. The data is observed at the ten-digit product level, and I define a six-digit HS product as subject to a prohibition if at least one of its constituent ten-digit goods is subject to such a prohibition. The full list of notices is as follows:

Shangwu bu, haiguan zongshu, guojia huanjing baohu zongju gonggao (2004) no. 55

Shangwu bu, haiguan zongshu gonggao (2005) no. 26

Shangwu bu, haiguan zongshu gonggao (2005) no. 50

Shangwu bu, haiguan zongshu, huanbao zongju gonggao (2005) no. 105

Shangwu bu, haiguan zongshu, huanbao zongju gonggao (2006) no. 63

Shangwu bu, haiguan zongshu, guojia huanjing baohu zongju gonggao (2006) no. 82

Shangwu bu, haiguan zongshu, huanbao zongju gonggao (2007) no. 17

Shangwu bu, haiguan zongshu gonggao (2007) no. 110

Shangwu bu, haiguan zongshu gonggao (2008) no. 22

Shangwu bu, haiguan zongshu gonggao (2008) no. 121

Shangwu bu, haiguan zongshu gonggao (2009) no. 37

Shangwu bu, haiguan zongshu lianhe gonggao (2010) no. 63

\section{A1.6 Export licenses, quotas, state trading and designated trad- ing}

Data for 2002 to 2012 on products requiring export licenses, subject to export quotas, or subject to designated trading or state trading requirements is taken from the annual official 
notices announcing this list of products. I do not include textiles and apparel products affected by the Multifiber Arrangement or subsequent bilateral agreements. I also exclude goods on lists of dual-use products subject to export quotas or lists relating only to smallscale border trade. Some categories of goods are moved from the 'main' list to the list of dual-use products during the sample period, and I do not include these products in any year. I do include a separately published list of tobacco products that are subject to export restrictions throughout the period. The data is observed at the ten-digit product level, and I define a six-digit HS product as subject to one of these policies if at least one of its constituent ten-digit goods is subject to the policy. The full list of notices is as follows:

Duiwai maoyi jingji hezuo bu, haiguan zongshu gonggao (2001) no. 17

Duiwai maoyi jingji hezuo bu gonggao (2001) no. 44

Duiwai maoyi jingji hezuo bu, haiguan zongshu gonggao (2002) no. 59

Shangwu bu, haiguan zongshu gonggao (2003) no. 64

Shangwu bu, haiguan zongshu gonggao (2004) no. 78

Shangwu bu, haiguan zongshu gonggao (2005) no. 85

Shangwu bu, haiguan zongshu gonggao (2006) no. 100

Shangwu bu, haiguan zongshu gonggao (2007) no. 101

Shangwu bu, haiguan zongshu gonggao (2008) no. 100

Shangwu bu, haiguan zongshu gonggao (2009) no. 125

Shangwu bu, haiguan zongshu gonggao (2010) no. 128

Shangwu bu, haiguan zongshu gonggao (2011) no. 98

\section{A1.7 Export prohibitions}

Data for 2002 to 2012 on goods prohibited from export is assembled from a set of ad hoc official notices. I drop any product (at the level of aggregation used in the relevant official notice) subject to an export prohibition in any year from the data used in the empirical analysis in all years. The full list of notices is as follows:

Duiwai maoyi jingji hezuo bu gonggao (2001) no. 19

Shangwu bu, haiguan zongshu, linyeju gonggao (2003) no. 27

Shangwu bu, haiguan zongshu, linyeju gonggao (2004) no. 40

Shangwu bu, haiguan zongshu, guojia huanjing baohu zongju gonggao (2005) no. 116

Shangwu bu, haiguan zongshu gonggao (2006) no. 16

Shangwu bu, haiguan zongshu gonggao (2006) no. 35

Shangwu bu, haiguan zongshu gonggao (2006) no. 87

Shangwu bu, haiguan zongshu gonggao (2008) no. 96

Shangwu bu, haiguan zongshu gonggao (2009) no. 110

\section{A1.8 Concordance between products and industries}

To define variables at the industry level, I use a National Bureau of Statistics concordance between four-digit Chinese industries and eight-digit HS products (according to the 2005 
Chinese product classification) kindly provided to me by Loren Brandt, Johannes Van Biesebroeck, Luhang Wang and Yifan Zhang. After aggregating to the six-digit level, I drop any six-digit products that are concorded to more than one two-digit industry, since I cluster at the two-digit industry level in the empirical analysis. I then average the relevant data across the six-digit products concorded to each industry.

\section{A1.9 Definition of nonagricultural products and industries}

I omit from the empirical analysis all eight-digit HS products defined as 'agricultural products' in China's official schedule of bound tariffs (available from the WTO web site); these are the products covered by the WTO's Agreement on Agriculture. So that I do not exclude agricultural products but include their major raw materials, I also drop fertilizers and pesticides from the analysis. I use a 2005 concordance of Chinese industries to HS products from China's National Bureau of Statistics (see above) to identify fertilizers and pesticides products in the HS data as those produced by the three-digit industries 'Fertilizer manufacture' and 'Pesticide manufacture'. I use the same concordance to classify industries into agricultural and agricultural raw materials industries, according to whether at least half of their products are agricultural goods or agricultural raw materials.

\section{A1.10 Definition of raw materials and capital goods}

I define raw materials as HS products identified by the UN Broad Economic Categories (BEC) classification as neither 'consumption goods' nor 'capital goods' (according to its correspondence with the System of National Accounts, which is included in the BEC documentation), nor as 'parts and accessories'. I also divide raw materials products into primary or semiprocessed raw materials according to whether they are classified by BEC as primary goods. I then use a 2005 concordance of Chinese industries to HS products from China's National Bureau of Statistics (see above) to classify industries as raw materials industries, and then into primary or semiprocessed raw materials industries, according to whether more than half of their products are in these categories. Capital goods and capital goods industries are classified similarly, defining both final capital products and their parts and accessories as capital goods.

\section{A1.11 Effective rates of protection}

Data on effective rates of protection by industry is derived using definitions from Corden (1966) and China's 2002 input-output table. I first concord products to input-output sectors using information from a 2005 concordance of Chinese industries to HS products from China's National Bureau of Statistics (see above). Ambiguous or missing concordances are coded using a concordance of products to 2007 input-output sectors from China's 2007 input-output table, or by hand when necessary. I define export taxes (or import tariffs) for each inputoutput sector as the simple average of export taxes (or import tariffs) across the six-digit products in that sector. For bound tariffs, I first reassign product-level tariff rates to be equal 
to 1999 applied tariffs whenever bound tariffs exceed 1999 applied tariffs. I then calculate each sector's input tariff or input export tax by using the shares of each input sector in the gross output of that sector as weights. I take information on the share of value added in gross output for each input-output sector from China's 2002 input-output table. I calculate the effective rate of protection due to tariffs for a sector as the difference between its tariff and its input tariff, divided by its value added share. Similarly, I calculate the effective rate of protection due to export taxes for a sector as the difference between its input export tax and its export tax, divided by its value added share.

\section{A1.12 Trade flows}

Data for 2002 to 2012, and for 1999, on trade flows is sourced from the UN COMTRADE database, using free on board (FOB) data provided by China as the source for information on Chinese exports by value and quantity (and import value for 1999). Data on world trade flows is also sourced from the UN COMTRADE database, and is equal to the total of all export flows reported by exporters. For all trade quantity data, I use only information on net weight in kilograms where available.

\section{A1.13 Upstream import tariffs and export taxes}

Data for 2002 to 2012 on upstream import tariffs and export taxes (for the analysis of Section 5) is derived in two ways. The first method uses China's 2002 input-output table. Products are concorded to input-output sectors using information from a 2005 concordance of Chinese industries to HS products from China's National Bureau of Statistics (see above). Ambiguous or missing concordances are coded using a concordance of products to 2007 input-output sectors from China's 2007 input-output table, or by hand when necessary. I define export taxes (or import tariffs) for each input-output sector as the simple average of export taxes (or import tariffs) across the six-digit products in that sector. I then calculate each sector's upstream export tax (or import tariff) by using the shares of each input sector in the total intermediate usage of the downstream sector, omitting the diagonal, as weights.

The second method uses product descriptions in the 2002 English-language six-digit HS classification and the 2002 to 2006 Chinese eight-digit product classifications (which are equivalent at the six-digit level). I first identify all primary six-digit products using the UN BEC classification, ignoring agricultural primary products and primary products in HS section 11 (i.e. textiles and apparel). I then identify all nonprimary HS products for which at least one of these primary raw materials is mentioned in the product description, with the goal of finding products made of that raw material. I thus exclude products with references such as 'other than (material)' and other irrelevant products such as machines for cutting the material. Using these criteria narrows the data to products made of 42 different primary

raw materials. I include in the final dataset only nonprimary products whose descriptions refer to exactly one of these materials, so that I may cluster by primary raw material. I then define upstream export taxes (or import tariffs) as the average export tax (or import tariff) 
across the six-digit HS products associated with a particular raw material (e.g. roasted and unroasted molybdenum ores).

\section{A1.14 Industry-level sales and export data}

Data for 2002 to 2007 on industry-level exports and sales as reported by firms in current Renminbi are based on industry-level tabulations of China's annual firm-level survey of industrial production, as collected by China's National Bureau of Statistics. This data includes all non-state industrial firms with sales above five million Renminbi and all stateowned industrial firms. Exports (sales) for each industry are defined as the total of exports (sales) for all firms in the industry, excluding those reporting negative output, sales, exports or employment. Since the 2002 survey data uses a older industrial classification, I concord these sectors to industries as defined after 2002 using a concordance provided by Brandt et al. (2012b).

\section{A2 Theory appendix}

In this appendix, I present a simple theoretical framework discussing the key mechanisms by which downstream import tariffs and an upstream export taxes can achieve similar economic effects. I posit a two-country economy with two industries, in which both countries produce in both industries, and define the outcome of interest as the pattern of employment of domestic factors across industries relative to the free trade equilibrium, which I call the "pattern of protection'. I then evaluate the real income implications of the policies achieving identical patterns of protection, in order to draw conclusions about policy choice.

Consider a world with two countries, home $(H)$ and foreign $(F)$, hereafter indexed by $c$. There are also two industries, upstream $(U)$ and downstream $(D)$. Each country produces one distinct product in each of the two industries (an Armington (1969)-type framework). A key assumption of the model will be that these goods are imperfectly substitutable in production (for upstream goods) and consumption (for downstream goods). Many firms in each country are assumed to produce in each industry under conditions of perfect competition. Each country also has an endowment $L$ of a single factor (labour) that is mobile across industries but not countries, and is inelastically supplied to firms. Trade in goods between the two countries is assumed to be costless in the absence of trade policy.

For simplicity, I will assume that production of upstream goods requires only labour $l$ and that there are constant returns to scale, so that quantity produced for a given firm in either country $c$ is $q_{U}^{c}=z_{U} l_{U}^{c}$. However, production of downstream goods requires a CobbDouglas combination of labour and the two upstream goods $m_{U}^{H}$ and $m_{U}^{F}$, with elasticity of 
substitution across upstream inputs of $\sigma_{U}>1:^{41}$

$$
q_{D}^{c}=z_{D}\left(\left(m_{U}^{H c}\right)^{\frac{\sigma_{U}-1}{\sigma_{U}}}+\left(m_{U}^{F c}\right)^{\frac{\sigma_{U}-1}{\sigma_{U}}}\right)^{\frac{\sigma_{U}}{\sigma_{U}-1} \beta}\left(l_{D}^{c}\right)^{1-\beta}
$$

Finally, the two downstream goods are consumed by labourers in each country according to constant elasticity of substitution (CES) preferences with elasticity of substitution $\sigma_{D}>1$ :

$$
U^{c}=\left(\left(x_{D}^{H c}\right)^{\frac{\sigma_{D}-1}{\sigma_{D}}}+\left(x_{D}^{F c}\right)^{\frac{\sigma_{D}-1}{\sigma_{D}}}\right)^{\frac{\sigma_{D}}{\sigma_{D}-1}}
$$

Given the model's symmetry assumptions, the allocation of labour across industries is identical in $H$ and $F$ in the free trade equilibrium: a share $1-\beta$ of each country's labour force is employed in production of downstream goods, $L_{D}^{H}=L_{D}^{F}=(1-\beta) L$. Moreover, because of the imperfect substitutability of products at each stage of the value chain, the two countries engage in bilateral trade of both upstream and downstream goods.

Now consider the implications for domestic industrial structure of the imposition by $H$ of a unilateral trade policy, by characterizing the change in the allocation of labour in $H$ relative to the free trade equilibrium. First, imagine that starting from free trade, $H$ adopts either a small ad valorem import tariff $t_{D} \equiv \tau_{D}-1>0$ on imports of downstream goods produced by $F$, or a similar tariff $t_{U} \equiv \tau_{U}-1>0$ on imports of upstream products. Also assume that all tariff revenue is returned to consumers in $H$ as a lump sum. Then either of these policies result in movement of labour in $H$ into the sector on which tariffs are imposed, i.e:

$$
\frac{d L_{D}^{H}}{d \tau_{D}}>0, \frac{d L_{D}^{H}}{d \tau_{U}}<0
$$

However, this shift in industrial structure occurs via different mechanisms in each case. To see this, define the expenditure share of the product of country $c$ in stage $k$ on that industry by country $c^{\prime}$ as $s_{k}^{c c^{\prime}}$. Then the familiar direct effect of either import tariff is to increase $s_{k}^{H H}$ at the expense of $s_{k}^{F H}$. In the case of a downstream tariff:

$$
s_{D}^{H H}=\frac{w^{(1-\beta)\left(1-\sigma_{D}\right)}}{w^{(1-\beta)\left(1-\sigma_{D}\right)}+\tau_{D}^{1-\sigma_{D}}}
$$

which increases in $\tau_{D}$, where $w$ is the relative wage $w^{H} / w^{F}$. The increase in domestic demand for $H$ downstream goods then leads to a rise in $w$, reducing the competitiveness of both of the goods produced by $H$ in both markets because of higher input costs. The net effect is to shift labour into the downstream industry in $H$ and out of the downstream sector in $F$ by the same amount, i.e. to generate a 'relocation effect' on industrial location:

$$
\begin{aligned}
d L_{D}^{H} & =\frac{1}{4} \frac{\beta(1-\beta) \sigma_{U} \sigma_{D} L}{\beta \sigma_{U}+(1-\beta)^{2}\left(\sigma_{D}-1\right)+(1-\beta)} d \tau_{D}>0 \\
d L_{D}^{F} & =-d L_{D}^{H}<0
\end{aligned}
$$

\footnotetext{
${ }^{41}$ This assumption about the relationship between the two countries' upstream products in the downstream production function is a simple analogue of the 'CES aggregate' approach taken in recent quantitative trade models such as di Giovanni et al. (2014) and Caliendo and Parro (2015).
} 
Now instead consider a tariff imposed by $H$ on imports of upstream goods. Like the downstream tariff, such a tax has a direct effect on the competitiveness of the goods that are taxed, in this case reducing the market share in $H$ of upstream goods produced by $F$. However, imposition of $\tau_{U}$ affects relative input costs in the two countries not only via changes in relative wages, but also by generating a wedge between the local price indices of upstream inputs in the two markets:

$$
\frac{P_{U}^{H}}{P_{U}^{F}}=\left(\frac{w^{1-\sigma_{U}}+\tau_{U}^{1-\sigma_{U}}}{w^{1-\sigma_{U}}+1}\right)^{\frac{1}{1-\sigma_{U}}}>1
$$

This input price disadvantage for downstream firms in $H$ serves to depress the relative competitiveness of their output at home and abroad, since:

$$
s_{D}^{H H}=s_{D}^{H F}=\frac{w^{(1-\beta)\left(1-\sigma_{D}\right)}}{w^{(1-\beta)\left(1-\sigma_{D}\right)}+\left(\frac{P_{U}^{H}}{P_{U}^{F}}\right)^{\beta\left(\sigma_{D}-1\right)}}
$$

which decreases in $P_{U}^{H} / P_{U}^{F}$.

Together, the direct encouragement of the upstream industry in $H$ via protection from import competition and the indirect discouragement of its downstream industry through changes in relative input prices again lead to a shift in industrial structure relative to free trade:

$$
\begin{aligned}
& d L_{D}^{H}=\left(\frac{1}{4} \beta(1-\beta) L-\frac{1}{4} \frac{\beta(1-\beta) \sigma_{U} \sigma_{D} L}{\beta \sigma_{U}+(1-\beta)^{2}\left(\sigma_{D}-1\right)+(1-\beta)}\right) d \tau_{U}<0 \\
& d L_{D}^{F}=-d L_{D}^{H}+\frac{1}{2} \beta(1-\beta) L d \tau_{U}>0
\end{aligned}
$$

However, trade policy no longer generates a simple 'relocation effect', since now $d L_{2}^{H}+d L_{2}^{F}>$ 0 . This is because an upstream import tariff induces substitution away from higher-cost CES bundles of raw materials and towards labour among downstream firms in $H$, distorting the global allocation of labour across industries. In contrast, a downstream import tariff taxes the final stage of production, which embodies the output of both stages of the value chain, thus avoiding such an inter-stage reallocation.

Next consider analogously defined ad valorem taxes $\nu_{D}$ and $\nu_{U}$ on exports of downstream and upstream goods produced by $H$ respectively, again assuming lump-sum redistribution of government revenue to consumers. Starting from the free trade equilibrium, either of these taxes may be shown to induce movement of labour in $H$ into the untaxed sector, i.e.:

$$
\frac{d L_{D}^{H}}{d \nu_{D}}<0, \frac{d L_{D}^{H}}{d \nu_{U}}>0
$$

A downstream export tax decreases foreign demand for $H$ downstream goods, leading to a fall in $w$, which increases the competitiveness of both goods produced by $H$ in each country. 
This results in the opposite 'relocation effect' to that caused by a downstream import tariff:

$$
\begin{aligned}
d L_{D}^{H} & =-\frac{1}{4} \frac{\beta(1-\beta) \sigma_{U} \sigma_{D} L}{\beta \sigma_{U}+(1-\beta)^{2}\left(\sigma_{D}-1\right)+(1-\beta)} d \nu_{D}<0 \\
d L_{D}^{F} & =-d L_{D}^{H}>0
\end{aligned}
$$

An upstream export tax, however, also increases the relative price of upstream goods in $F$, resulting in an input price advantage for the downstream industry in $H$; i.e. $P_{U}^{H} / P_{U}^{F}<1$. This not only stimulates production of $H$ downstream goods, but as with an upstream import tariff, also leads to a distortion in the global allocation of labour across industries:

$$
\begin{aligned}
d L_{D}^{H} & =\left(\frac{1}{4} \frac{\beta(1-\beta) \sigma_{U} \sigma_{D} L}{\beta \sigma_{U}+(1-\beta)^{2}\left(\sigma_{D}-1\right)+(1-\beta)}+\frac{1}{4} \beta(1-\beta) L\right) d \nu_{U}>0 \\
d L_{D}^{F} & =-d L_{D}^{H}+\frac{1}{2} \beta(1-\beta) L d \nu_{U}<0
\end{aligned}
$$

where again $d L_{D}^{H}+d L_{D}^{F}>0$.

Thus, in this simple two-industry framework, labour is shifted into the downstream industry by a higher import tariff on $D$ or lower import tariff on $U$, but by a lower export tax on $D$ or higher export tax on $U$. In other words, the import tariffs and export taxes that generate the same patterns of protection are imposed on different industries. Moreover, either a higher export tax or lower import tariff on the upstream industry may increase the input price advantage (or decrease the disadvantage) of the downstream industry using those inputs. Both of these predictions of the model are relevant to the analysis of Section 4 of the paper.

An additional result of the model is also notable: a downstream import tariff achieving the same shift of labour into the downstream sector as an upstream export tax does so at a lower cost (i.e. larger benefit) to aggregate domestic real income. ${ }^{42}$ If governments prioritize the protection of downstream industries (as suggested by the ubiquity of tariff schedules affording greater protection to downstream sectors) but take account of real income when choosing the instrument by which this is accomplished, this result provides a possible reason for the popularity of import tariffs as compared to export taxes in practice. ${ }^{43}$

The proportional effect of a downstream tariff on real income in $H$ is determined by the gain in nominal income $Y^{H}$ (via wage growth and government revenue), offset by the rise in the consumer price index in $H, P_{D}^{H}$ (due to tariffs on $F$ goods and higher nominal labour

\footnotetext{
${ }^{42}$ The downstream export subsidy or upstream import subsidy achieving the same allocation of labour also do so at a higher cost to real income relative to a downstream import tariff. This is a less surprising result, given the well-known negative effects of trade subsidies on domestic terms of trade.

${ }^{43}$ As noted in Section 4, Balassa (1965) and Cadot et al. (2004) provide empirical evidence of widespread 'tariff escalation'. Cadot et al. (2004) also outline a political-economy rationale for the systematic favouritism of downstream sectors, based on Grossman and Helpman (1994). For cross-country evidence that export taxes are rarely used in practice, but used more often on upstream goods, see Solleder (2013). Finally, see Ethier (2004) for an alternative rationale for the rarity of export taxes, which he suggests constitutes a puzzle for the terms-of-trade-based theory of trade agreements proposed by Bagwell and Staiger (1999).
} 
costs for firms in $H$ ), relative to free trade:

$$
\frac{d Y^{H}}{Y^{H}}-\frac{d P_{D}^{H}}{P_{D}^{H}}=\left(d w+\frac{1}{2} d \tau_{D}\right)-\left(\frac{1}{2} d \tau_{D}+\frac{1}{2} d w\right)=\frac{d L_{D}^{H}}{\beta \sigma_{U} L}>0
$$

Thus, for the tariff that leads to $d L_{D}^{H}=k L$, the associated change in real income in $H$ is $k /\left(\beta \sigma_{U}\right)>0$.

However, the implications of an export tax achieving $d L_{D}^{H}=k L$ on real income in $H$ are as follows:

$$
\begin{aligned}
\frac{d Y^{H}}{Y^{H}}-\frac{d P_{D}^{H}}{P_{D}^{H}} & =\left(d w+\frac{1}{2} \beta d \nu_{U}\right)-\left(\frac{1}{2} d w+\frac{1}{4} \beta d \nu_{U}\right) \\
& =\frac{k}{\beta \sigma_{U}} \underbrace{+\left(\frac{1}{2} \beta-\frac{1}{4}\right) d \nu_{U}}_{\text {revenue }} \underbrace{-\frac{1}{4}\left(\frac{1-\beta}{\sigma_{U}}\right) d \nu_{U}}_{\text {distortion }} \underbrace{-\frac{1}{4} \beta d \nu_{U}}_{\text {pass-through }} \\
& =\frac{k}{\beta \sigma_{U}}-\frac{1}{4}(1-\beta)\left(\frac{\sigma_{U}+1}{\sigma_{U}}\right) d \nu_{U}
\end{aligned}
$$

Given that $d \nu_{U}>0$, this is an unambiguously smaller gain in real income than in the case of a downstream import tariff. The difference between the two gains is due to three separate effects, highlighted in the equations above.

The first effect, of ambiguous sign, results from the fact that government revenue from the two instruments depends on the share of value added in the free-trade economy accruing from the upstream stage. If the two stages are of equal importance to gross domestic product under free trade - i.e. if $\beta=\frac{1}{2}$ - then the revenue implications of a tax on either sector are identical.

The second effect, which is negative, derives from the aforementioned distortion to the world allocation of labour across stages induced by an upstream export tax (but not a downstream import tariff), which reduces real income in both countries. This effect decreases in $\sigma_{U}$ because this distortion has a smaller impact on real income if raw materials from $F$ are more substitutable for those from $H$, since downstream firms in $F$ can more readily replace higher-cost upstream goods from $H$ with local raw materials rather than hiring more labour.

The final effect, also negative, is due to the fact that part of the price increase resulting from the export tax is paid for by consumers in $H$ via imports of downstream goods from $F$. To better understand this pass-through effect, imagine instead an analogous model of two final goods with equal Cobb-Douglas consumption shares and identical production functions linear in labour. In such a model, the effects on sectoral distribution and real income of an import tariff on one sector and an export tax on the other are identical. This is in part because the implications of each of the policy instruments for government revenue and production choices are the same. But it is also because of the key insight of Lerner's (1936) original symmetry result: that an import tariff, which raises both relative nominal wages and local prices, and an export tax, which depresses relative nominal wages and causes price increases abroad, result in the same shift in a country's terms of trade. In the two-stage 
model here, this symmetry does not hold because the price increases resulting from an export tax instead accrue partly in $H$ itself. 